\section{Tracing the History of Museums in Egypt from the Ptolemaic Period to the Fall of Mohamed Ali's Dynasty (323 BC-AD 1952)}

Rania Ali Maher and Noha Moustafa Shalaby

\section{Abstract}

Establishing museums was an ancient tradition that was only revived at the beginning of the Renaissance period. In the distant past, Egypt was the home of the first institution-termed museum that was founded and very well maintained by the early Ptolemies. In the modern era, its rulers of Mohamed Ali's dynasty sought to accentuate the power of the state by founding various types of musenims that were for the most part he first of their kind in the region. Under the monarchy, museum notion witnessed a dramatic change. Such institutions were mostly used as powerful tools to inspire the public in the course of nation building, so as to finally form a distinctive modern Egyptian identity, which is in fact the outcome of long episodes of various successive eras. Besides unfolding the past, museums foster the sense of national allegiance among the public and reflect the modernity of the state of its time; therefore, this article aims to explore the history of the Egyptian museums from ancient to modern times until 1952

\section{Introduction}

The term museum comes from the Greek word Movøziov (Mouseion) meaning the temple or the haunt of the Muses, ${ }^{1}$ the nine daughters of the god Zeus, who presided over arts and sciences, ${ }^{2}$ and whose mention was as early as the Homeric poems. ${ }^{3}$ The ancient meaning of the term is an academic and religious community of scholars, ${ }^{4}$ that is a religiously toned research institute. Curiously, Horapollo stated that among the interpretations of the "seven letters included within two fingers" (which may apply to the symbol of the ancient Egyptian goddess Seshat) is muse." Such symbol was never precisely identified;" however, the total number of the signs constituting it is nine, which is the number of Muses in Greek mythology. A possible link between Seshat and the Muses, who were both goddesses of knowledge, could be thus proposed.

The concept of Mouseion may be best commenced by the Greek Philosopher Pythagoras in the $6^{\text {th }}$ century BC with a school in Croton in the southern coast of Italy that was called by the inhabitants «the temple of Muses». Then the idea was moved to Athens, which housed two schools in the Classical Period: the Academy of Plato and the Lyceum of Aristotle. In these institutions, the scholars were centered round a shrine of Muses, thus the study of philosophy there was considered as a ritual to the nine goddesses. ${ }^{7}$ Worthy of note is that Pythagoras who originated the Mouseion notion was a student of a priest in Egypt. ${ }^{8}$

\footnotetext{
Henry George Liddell and Robert Scott, A Lexicon: Abridged from Liddell and Scott's Greek-English Lexicon, (Oxford: Clarendon Press. 1979). 453 2 Charles F. Baker and Rosalie F. Baker III, Ancient Greeks: Creating the Classical Tradition, (Oxford University Press, 1997), 43 3. William W. Minton, “Homer's Invocations of the Muses: Traditional Patterns,", Transactions and Proceedings of the American Philological Association 91
1960): 292-309: Elisabeth Minchin, “The Poet Appeals to His Muse. Homeric Invocations in the Context of Epic Performance," The Classical Journal 91 , 10.1 (Oct-Nov.1995): 25-3

4 Andrew Erskine, "Culture and Power in Ptolemaic Egypt: The Museum and Library of Alexandria," Greece and Rome 42, no. 1 (Apr. 1995): 38 5 Alexander Turner Cory, The Hieroglyphics of Horapollo Nilous, Book II (London: William Pickering, 1840), 106; George Dyer, Poetics: Or, Series of Poems, and Disquisitions on Poetry II (London: J.J Johnson and co. 1812), 3; G. A. Wainwright, "Seshat and the Pharaab,"” Journal of Egyptian Archaeology
26 (1941): 35 , 36 n. 1. However, Capart rejected Horapollo's interpretation, see Jean Capart, "Bulletin critique des religions de l'Egypte 1906 ET 1907 ," Revue de 'histoire des religions, vol. 59 (1909): 7 .

6 For analysis and discussion of the symbol, see Dušan Magdolen, "The Development of the Sign of the Ancient Egyptian Goddess Seshat down to the End of the Old Kingdom: Analysis and Interpretation I-II," Asian and African Studies 14, no. 2 (2005): 44-55, 196-227; id.. "“The Develomment of the Sign of the

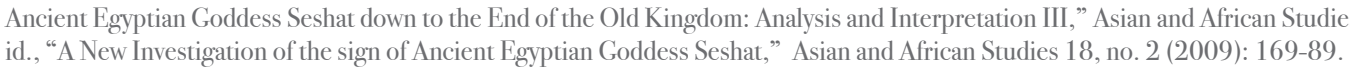
77 Edouard Schuré, Pythagoras and the Delphic Mysteries (London: William Ride \& Son, 1906), 66-7; Alma Stephanie Wittlin, The Museum. Its History and its Tasks in Education (London: Routledge \& K. Paul, 1949), 1; Thomas K. Simpson, “The Museum as Grove of the Muses," Journal of Museum Education Clementefter
}

Knowing that there were places for learning within the precincts of Egyptian temples, ${ }^{9}$ the idea of education within a temple, preferably dedicated to the goddesses of knowledge, could have been then transmitted to Pythagoras who applied it in Italy.

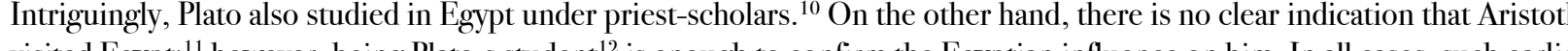
visited Eypl, ". they were b.e. they were boh

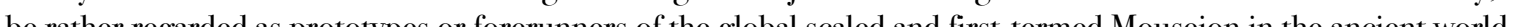

\section{Alexandria: Birthplace of Materializing Museum Notion}

Upon seizing control of Egypt, Ptolemy, son of Lagus, needed to be enveloped in a Hellenic mantle so as to legitimize his rule as a successor of Alexander. Within this context, he succeeded in conveying the body of Alexander to be buried in Egypt, moved the capital to the new city founded by Alexander and named after him, and managed in promoting a scholarly activity through the establishment of the celebrated Museum and Library of Alexandria ${ }^{15}$ and enticing intellectuals, especially from Greece, to settle in Egypt; ${ }^{16}$ thus creating an institution similar to the Lyceum of Alexnanderss tutor, Arsitotle, at Athens. ${ }^{17} \mathrm{It}$ is stated that Demetrius of Phalerum, who was a student of Theophrastus, ${ }^{18}$ and whom had been unfairly ousted from Athens, went to Ptolemy Soters court in Alexandria and became among the kingss friends, ${ }^{19}$ most likely advised Soter to create the museum an library, the collection of the latter had been so much enlarged under Ptolemy Philadelphus who had given Demetrius, then the so as to seek their inspiration. ${ }^{22}$ Strabo described the museum as being a part of the roval palace in the Bruchium quarter, having

9 These were called centers of learning with libraries in temple annexes where a broad range of disciplines were taught, see Dieter Arnold, Lanny Bell, Ragnhill Bjerre Finnestad, Gerhard Haeny and Byron E. Shafer, see Temples of Ancient Egypt (Ithaca, New York: Cornell University Press, 1997), 228. For more details on this topic, Fayza M. Haikal, "Private Collections and Temple Libraries in A
eds. Mostafa El-Abbadi, Ommia M. Fathalla (Leiden and Boston: Brill, 2008), 39-54.

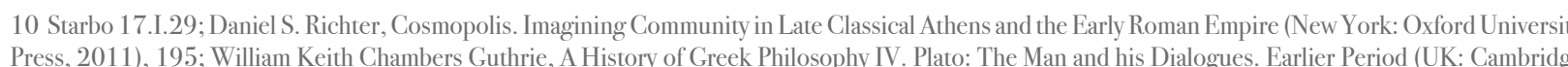
Press, 2011), 195; William Ke
University Press, 1975), 15 . and his usage of the verbs suggessts that he was the one who did the action. Theóohilie Obenga and Amon Saba Saakana, Ancient Egypt and Black Africa. Student's Handbook for the Study of Ancient Egypt in Philosophy, Linguistics, and Gender Relations (London: Karnak House, 1992), 64

12 Samuel Henry Butcher, Aristotte. Poetics, Mineolla (Mineola, New York: Dover Publications, 1997), iii

13 For instances of the term "Academy" in Classical sources regardding Plato's institution, see Cicero, De Finibus 5.1: "arranging affernoon stroll in the acadeny

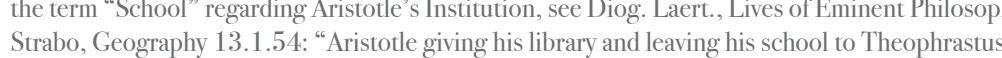

14 Henry T. Rowll, “A Home for the Muses," Archaeology 19 , no. 2 (April 1966): 79.

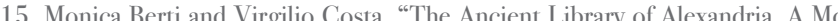
(The Ancient_Library of Alexandria__A_Model_for_Classical_Scholarship_in_the_Age_of_Million_Book_Libraries. Despite some accounts attributing the foundation of the Librar

16 For the well knownininger 16 For the well-known intellectuals under Ptolemy Soter

17 Jeffrv Abt. "The Origins of the Public Library," in A Companion to Museum Studies, ed. Sharon Macdonald (UK: Blackwell, 2006): 116

18 Diog. Laert. 5.75. He may also have been a student of Aristoote and had activities and literary production in his School. Berti, “The Ancient Library or

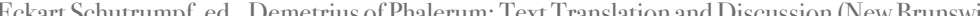
19 Plutarch, De Exilio 601F; William W. Fortenbaugh
and London: Transaction Publishers 2000), 79, no. 35 .

20 Delfim Leao, "Plutarch on Demetrius of Phalerum: The Intellectual, the Legislator and the Expatriate," Symposion 2017, Vorträge zur Griechischen und Hellenisisischen Rechtsgeschichte (2018): 443

21 Fortenbaugh, Demetrus of Phalerum, 111, no. 58B; Aristeas, The Letter of Aristeas to Philocrates 9-10 (Recognizing the king as Philadelphus can be

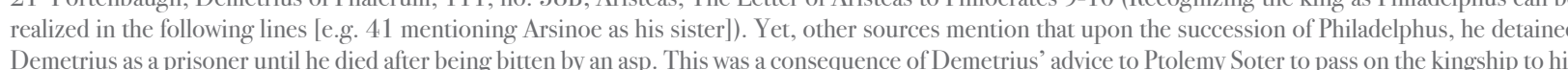
Demetrius as a prisoner until he died after being bitten by an asp. This was a consequence of Demetrius' advice to Ptolemy Soter to pass on the kingship to hy
children to Eurydice, See Diog Laert. 578 . 22 Macleod, The Library of Alexandria, 62 
a public walk and a place furnished with seats in addition to a large dining hall for the museum scholars. ${ }^{23}$ Such description bears

the study of arts and sciences; that is it was mecty a bect Museum, however, had some objects including statues of thinkers, astronomical and survical instruments, elephan and a never meant for public disply. Such acquisition of valuable material gives it the validation of being akin to modern musun $1^{27}$ The museum a dibrary functioned for nearly 6 centuries when they were finally destroyed Several accounts badbeen given The re of his vist

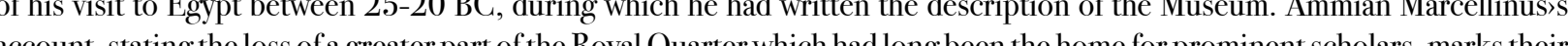
derir other museums were established during the Roman Republic time, ${ }^{29}$ e.g. Polybius pointed out to the presence of a museum in

\section{Rome: Formulating the Concept of Public Display}

Roman individuals s tendency of acquiring private collections increased after their conquests reaching its peak in the Republic last century; the emperors had halls in their palaces used as private museums. But this was discouraged by the generals; Agrippa $^{31}$ delivered a speech to the public calling for opening the treasures of the palaces to the public for purposes of education and raising the intellectual awareness; then Julius Caesar forbade private artifact collecting and made all of them state property. ${ }^{32}$ Hence, the idea of public display was initiated. The Romans displayed paintings and sculptures, brought from their conquests, in gardens, temples, theatres and baths. In the $2^{\text {nd }}$ century $\mathrm{AD}$, Emperor Hadrian specifically was a pioneer in creating what is called in the modern sense can open-air museums when he reconstructed a number of landmarks that he had seen during his

\section{From Medieval Age to the Renaissance: Between Absence and Revival of Museums}

The Medieval Age is generally characterized by the absence of true museums and the rising of private collections. Throughout the various Islamic periods, the Arabs had the tradition of collecting valuable objects; they had private collections in the palaces of their Caliphs or Sultans and Emirs/Princes (especially Abbasids, Fatimids and Mamluks) for the purposes of showing off and boasting. Moreover, it is very likely that the Fatimids were the first to initiate the concept of specialization in museums/ collections; they possessed number of houses, the contents of each house (Dar) were of only one type (for example, Dar AlAsleha [House for Weapons], Dar Al-Seroug (House for Saddles), Dar Al-Tara'f [House for Antiques] ...etc). On the other hand, the Arabs never knew public museums, but rather private small museums. It is nearly about the same time of the fall of the Islamic rule at Al-Andalus in the late $15^{\text {th }}$ century, there emerged a wave of collecting high quality objects by European private

23. Strabo, Geography 17.1.8.

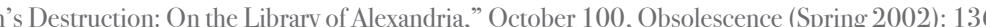

25 Paula Young Lee, "The Musaeum of Alexandria and the Formation of the Muséum in Eighteenth-Century France," The Art Bulletin 79, no. 3 (Sep. 1997):

26 Edward P. Alexander and Marry Alexander, Museums in Motion. An Introduction to the History and Functions of Museums (Lanham: Altamira Press,
2008), 3.

27 Shadia Mahmoud “"The Development of Archaeological and Historical Museums in Egypt during the Nineteenth and Twentiect Centuries: Imperialism,
Nationalism, UNESCO Patronage, and Egyptian Museology Today,” (PhD diss., Texas Tech University, 2012), 34-5. 28 Berti, “The Ancient Library of Alexandria," 3 ; Ammian Marcellinus, Roman History 22.16.15; For more information on the destruction of the Library, see

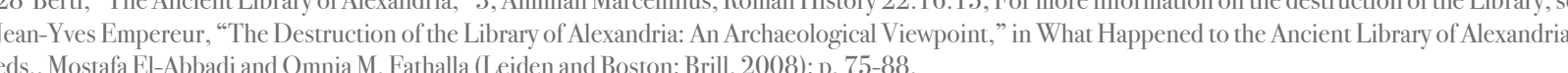
29 Berti, “The Ancient Library of Alexandria”,

30 Polybius, Histories 8.27.1 (the city name 'Tarentines' is mentioned in 8. 24. 1;8. 25. 2).

31 The Roman general, Marcus Vipsanius Agrippa, was a close friend and son in, law of 0 .

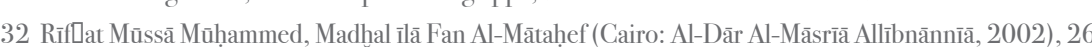

33 Alexander, Museumsin Hetion 45 individual $\mathrm{s}^{34}$ starting with Italy and France, ${ }^{35}$ and later on to other European countries, notably England. ${ }^{36}$ Such connection was absolutely not a coincidence; it is possible that the idea of forming collections, which is the basis of museum concept, was transmitted to Europe, the same way as Arab sciences and cultures, through Spain by France and Italy. ${ }^{37}$ The way to both cor for such hypothetical hicory were ${ }_{39}$ he thasures take formed the

The Renaissance witnessed museums revival. At the beginning of that period, the public museum in its modern sense had been originated by the Europeans. They adopted the idea of collections, developed it and maximized its benefit by changing the ownership from private individuals to the public. ${ }^{40}$ The earliest example existed in Italy in 1471 ; that is, the Capitoline round doted by Pope Sivus IV to be alced in the Palazo dei Conservatori on (2) Pope Julius II t the Cortile del Belvedere in $1506{ }^{43}$ Both modest nuclei of Capitoline and Vatican were then by later dowins The

In

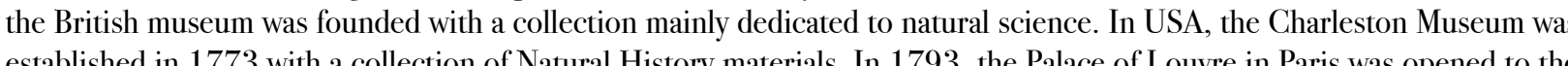
public that may well be considered as the first oreat national art museum ${ }^{44}$ In the $19^{\text {th }}$ century, there occurred a chane in the way of the exhibition from being haphazard to follow a specific system. This began in German and Swiss museums, whose directors placed the objects in a chronological order in what was called Period Rooms ${ }^{45}$ Of the great museums in USA the had been established in that century in 1870 are the Metropolitan Museum of Art in New York and the Museum of Fine Arts in Boston ${ }^{46}$ and the berinning of the $20^{\text {th }}$ entury, the number of museumer Russia nearly at the

\section{Rediscovering the Distant Past of Egypt and the Necessity for its Safeguarding}

Before the decipherment of hieroglyphics, the Westerns knew very little about Egypt through the antiquities that were moved to their countries or the images from the historical places drawn by travelling artists or the more comprehensive work "Description de LEgypte". However, the effort of several European scholars, particularly Thomas Young and Champollion, decoding the

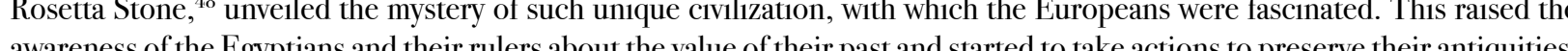

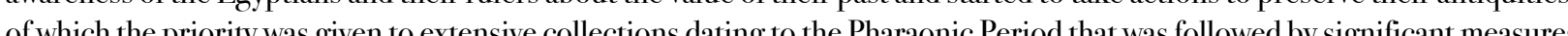
to establish other homes for the three successive periods of Egypt.

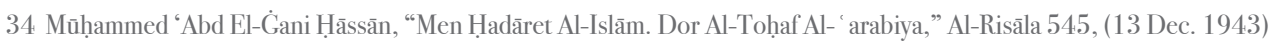

35 Alexander, Museums in Motion, 24-5

36 In the 18 th Century, the flood of collecting was transferred to England, in which its stately homes had brought together the finest paintings, sculptures,
architectural elements and landscape models. Sporadically, some collectors permitted visitors to view their collection. Alexander. Muscums in Motion, 24-7. 37 Hässän, "Men Hadäret Al-slämm."

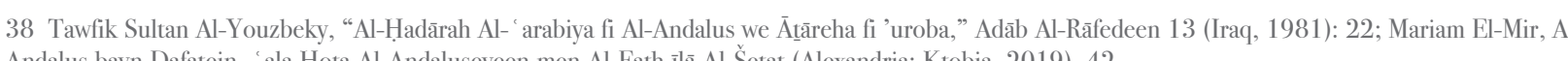

39 Hâssan, “Men Hadàret Al-ssläm”; Peter Wein, Arab Nationalism. The Politics of History and Culture in the Modern Middle East (London, New York

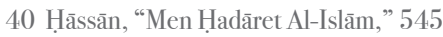

41 Lionel Casson, "II Palazzo dei Conservatori," Archaeology 25, no. 2 (April 1972): 96

42 Casson, "II Palazzo dei Conservatori," 102; Roger Cushing Aikin, "Romae de Dacia Triumphantis: Roma and Captives at the Capitoline Hill," The Ar

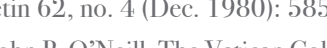

43 John P. ONeill, The Vatican Collections: The Papacy and Art (New York: Metropolitan Museum of Art, 1982), 57-58.

44 Alexander, Museums in Motion, 5-6, 27-9.

46 Alexander, Museums in Motion,7; Abt, “The Origins of the Public Museum," 130-31.

47 Minharmed Malbolla

48 F. LL. Griffith, "The Decipherment of the Hieroglyphs," Journal of Egyptian Archaeology 37 (Dec. 1951): 39. 


\section{The Earliest Initiatives to Establish a Museum in Modern Egypt}

The initial steps for creating a national museum in Egypt goes back to the reign of Mohamed Ali Pasha (r. 1805-1848), the founder of modern Egypt, when he issued a decree in 1835 prohibiting the exportation of all kinds of antiquities and ordering the establishment of a museum for the exhibition and the preservation of such artifacts. ${ }^{49}$ Yusuf Diva Effendi was entrusted to transform this task into a reality under the supervision of Rifa a El-Tahtawy ${ }^{50} \mathrm{Close}$ to the school of Foreign Languages, Diya housed the discovered antiquities in a building constructed by Engineer Yousef Hekekyan in the Ezbekiyeh gardens of Cairo. This museum was either known as the Museum of Sheikh Rifa'a or Al-Antiqakhana. After putting the blame on the Europeans for plundering the antiquities, Mohamed Ali demonstrated his shrewd prowess in the mentioned decree by assuming that the proposed scheme would be in the Europeans' interests and he posited foreigners instead of the locals as the projected visitors of the museum. Fl-Tahtawy and Diva optimized the museum by enlarging the collection and preserving the artifacts. They also appointed inspectors all over the country to send any discovered antiquities to the museum

Nevertheless, the decree posed little effect, as the despoliation of the Egyptian antiquities continued by foreign excavators and collectors. Even the British and the French Consuls in Cairo at the time, Henry Salt and Bernardino Drovetti, competed with each other in carrying off antiquities to enrich their museums in Europe. ${ }^{22}$ In 1942, Mohamed Ali somberly informed Richard Lepsius, a German Egyptologist and linguist, that his idea of creating a museum had failed, as "the excavations are made without knowledge and energy, the Pasha is cheated by those who work, and no one there takes any interest in a museum....533

It was also reported by Sir John Gardner Wilkinson, an English pioneer Egyptologist, that there was another museum in one of the palaces of Ibrahim Pasha-Mohamed Ali's son. However, by 1841, only a few remnants of this collection had been found like "mass of broken mummies, cases and various fragments." ${ }^{4}$

Following the deaths of Ibrahim Pasha and Mohamed Ali, the new Viceroy Abbas Helmy I (r. 1848-1854) paid intermittent attention to antiquities, ordering the transfer of the remaining objects of Rifa'a's Museum to the School of Engineering in Boulaq in October 1849. Later, in 1851, it was decided that a small hall used for the storage of food and coats of the employees of the Ministry of Education within the citadel would be a sufficient place to store the objects that had not yet been given away orstolen. ${ }^{5.5}$

By 1855, the story of Egypt's first indigenous museum came to an end when Abbas Helmy I gifted part of the collection to the Ottoman Sultan Abdul-Azzz and then his successor Said Pasha (r. 1854-1863) presented what was left to Archduke Maximilian of Austria as a souvenir during his official visit to Egypt, believing that the Egyptian antiquities could be used as a perfect diplomaticleverage..$^{56}$

Despite the failure of such a project, the Egyptian state's initial movement to form a museum during the early years of the nineteenth century illustrates the enlightened visions of Mohamed Ali Pasha and the Egyptian intelligentsia towards the concept of dedicating a building for the exhibition and preservation of the Egyptian antiquities.

Ignoring these abortive initial endeavors of Mohamed Ali and Rifa a Al-Tahtawi, most of the Egyptologists regarded Mariette

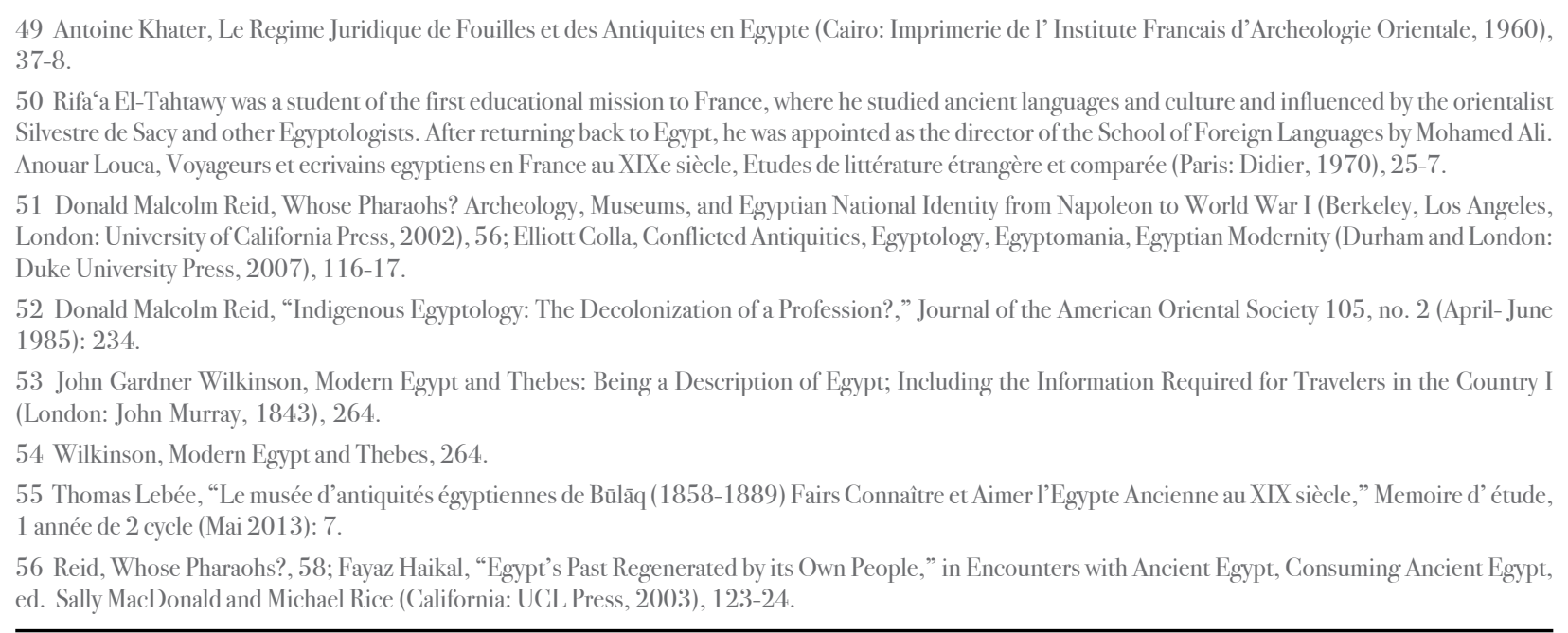

Pasha $^{57}$ as the legitimate founder of Egypt first national museum in 1863.

Due to the tenacious attempts of Egypt viceroys to ban trade in the Egyptian antiquities and because of the growing AngloFrench political and Egyptological rivalry, France worked on having the upper hand on the excavations in Egypt through Mariette. Accordingly, Ferdinand De Lesseps, with Napoleon III's backing, succeeded in convincing Said Pasha in 1858 to create the Egyptian Antiquities Service under the direction of Mariette himself with an annual salary of 18000 Francs. ${ }^{58}$ Seeking to put obstacles in front of the agents of the different European missions who were justifying their plundering of the Egyptian antiquities on the grounds of Egypt's incompetence of preserving and supervising its own heritage, Mariette persuaded Said Pasha to execute the essential prerequisite of self-establishing an Egyptian national museum..$^{59}$ This museum came to reality in 1863 under the reign of Ismail Pasha (r. 1863-1879), who was looking for representing himself as an enlightened European-style sovereign. Ismail thought of a huge complex with museums for pharaonic, Greek and Islamic antiquities. At the same time, he demonstrated a new perspective of making these museums accessible to the natives to teach them the history of their country, as he believed that pride in Egypt past was crucial for national revival. ${ }^{60}$

Ismail inaugurated Boulaq Museum in the presence of one of Napoleon III's deputies on $16^{\text {th }}$ of October 1863 with a total cos of about 60000 pounds, funded mainly by the state and partially by Mariette's own money. At that time, Boulaq Museum was appraised as the world's largest museum of antiquities. ${ }^{61}$

With the aim of serving the Egyptians interests as advised by Ismail, an Arabic guidebook of the museum was issued. Its contents were addressed to readers of Islamic background. Affirming compatibility between Pharaonic belief and Islamic religion to correct the false image about the ancient Egyptians who were portrayed as being polytheistic, the text began with a bismillah invocation, invoked Prophet Mohamed and declared that this museum was established for the purpose of introducing the Egyptians to the history of their ancestors. It presented the modern Egyptians as the direct descendants of the pharaohs. Aiming to crack the European monopoly, Ismail also ordered the construction of the school of the Ancient Egyptian Language to generate Egyptian calibers to work alongside foreigners in the museum. ${ }^{63}$

In the wake of Ismail's modernization projects of Cairo, the government let bids in 1873 for the foundation of a great new museum in Gezira. However, the proposed project vanished because of the fiscal crisis that broke out ${ }^{6 /}$

Being on the bank of the Nile, Boulaq Museum had flooded in 1878 and was closed until 1880 when it was renovated and reopened to the public. By 1890, the museum could not accommodate the orowing collections, a matter that promoted Khedive Tawfik (r. 1879-1892) to hand over Ismail Pasha's palace at Giza as a new place for the Museum ${ }^{6.5}$

Under the British occupation and with the displacement of the Museum to the Giza Palace, a new perplexing phase began when relations between the Antiquities Services dominated by the French and the British interests in Egypt were strained. During thi period, the Society for Preservation of the Monuments of Ancient Eoypt in Britain started to press for more British engagemen in the archaeological service as well as the necessity of constructing a new museum building. Accordingly, Lord Cromer, the British Consul and the de facto ruler of Egypt, decided to allocate a budget for the construction of a new museum. Khedive Abbas Helmy II (r. 1892-1914), who ascended to the throne of Eoypt after the death of Khedive Tawfik, laid the foundations i April 1897; however, financial constraints delayed the opening.6" for Louvre Museum. Upon his arrival, he started to work on excavations at Saqqara, succeeding in sending more than 7000 antiquitites to Louvre withou
taking the permission from the Egyptian government. Haikal, "Egypt's Past Regenerated by its Own People," 124 ; Tim Murray, Milestones in Archaeology: A taking the permission from the Egyptian government. Haikal, “Egypt's Past Regenerated by its Own People," 24 ; Tim Murray, Milestones in Archaeology: A
Chronological Encyclopedia (Santa Barbara: ABC-CLIO, 2007), 226; Christian Orsenigo, , Turning Points in Egyptian Archeology 1850-1950," in Egypt and the Pharaahs from the Sand to the library, Pharaonic Egypt in the Archives and Libraries of the Universita degli Studi di Milano, ed. Partrizia Piacentin
(Universita degli Studi di Milano, 1923), 117-18.

58 Reid, "Indigenous Egyptology," 234

59 Jeanette Greenfield, The Return of Cultural Treasures (London: Cambridge University Press, 1996), 92-3.

60 Reid, Whose Pharaohs?, 104

61 It is worth mentioning that Ismail refused to enter the museum and remained in the garden during the opening ceremony, owing to his nauseous feeling
about being in a building that had mummies in it. Reid, Whose Pharaohs? 107 ; Greenfield, The Return of Cultural Treasures, 93 . 62 Lebée, "Le musée d'antiquités égyptiennes," 47.

63 In 1874, the school was closed due to Mariettes Egyptians would threaten France's monopoly on Egyptian antiquities. Reid, "Indigenous Egyptology," 235

64 Reid, Whose Pharaohs?, 135-36.

65 E. A. Wallis Budge, Cook's Handbook for Egypt and the Egyptian Sudan, third edition (London: Thos. Cook \& Son, Ludgate Circus, E. C, 1911), 422 66 Thomas G. H. James, Excavating in Egypt, The Egypt Exploration Society 1882-1982 (London: University of Chicago Press, 1982), 29-30; Reid, Whose
Pharaohs? $182-83,195$. 
After almost five years, the Egyptian antiquities found its last destination when the new museum (current museum in Al-Tahrir Square) was officially opened on $15^{\text {th }}$ of December 1902 by Khedive Abbas Helmy II, with the attendance of Lord Cromer and other 500 Egyptians and foreign dignitaries. ${ }^{67}$ The total cost of construction was estimated to be $f \mathrm{E} 189220 .{ }^{68}$ It is considered as one of the oldest museums in the world to have a building that was specially constructed for use as a museum rather than being a palace or an old edifice rehabilitated for this purpose. ${ }^{99}$ The design that the French architect Marcel Dourgnon devised exuded Western colonial supremacy, by decorating the façade in a neo-classical style with statues of the European Egyptologists worked in the museum and a text written in the Latin Language with which the Europeans often used for the decoration of their monuments. ${ }^{70}$ Following the European model, the museum is provided with a library, laboratory and a vast open area for future expansions. ${ }^{71}$ It is beyond the scope of this paper to discuss the Egyptians' struggle for autonomous control over their own heritage from the Westerners; however, it is worth mentioning that the Egyptian Museum remained under French control for almost hundred years since the time of the appointment of Mariette Pasha as director of the Antiquities Service by Said Pasha till the overthrow of King Farouk in $1952^{72}$

\section{- Museums under Khedival Egypt}

In addition to the Egyptian Museum that was established mainly for the antiquities of the Pharaonic period, Khedival Egypt witnessed the foundation of three other archaeological museums, which are the Arab Art Museum, the Graeco-Roman Museum and Coptic Museum; each represents an important era of Egypt's long history. The establishment of these four museums were among many other great projects that Egypt witnessed in the wake of the Khedivial project of forming a modern nation-state. While these four museums were mainly products of European initiative, their establishments were under the auspices of Egypt's

\section{- Museum of Arab Art (Museum of Islamic Art)}

Despite the fact that the Westerns, passion for Pharaonic relics preceded their wave of admiration for what was called Arab Art (later termed Islamic Art), attempts to convey images from Islamic Cairo made its debut in the late $18^{\text {th }}$ century through the travelling artissts. Louis-François Cassas, the French draftsman, made remarkable sketches of the Mosque of El-Sultan Hassan. ${ }^{73}$ In the early $19^{\text {th }}$ century, Pascal-Xavier Coste, the French architect, made impressive drawings of the architecture of Cairo during his stay in Egypt (1817-1827) serving as chief architect of Mohamed Ali; and he concluded by the publication of "Architecture Arabe ou Monuments du Caire" in 1837. Also, Emile Prisse D)Avenne, French engineer and draftsman, arrived in Egypt in 1827 and stayed for 19 years; he made an excellent survey on Islamic art and architecture materialized in his publication “Lart arabe daprès les monuments du Kaire, depuis le VII c siècle jusquàla fin du XVIII' siècle, Paris, 1877”. Such appreciation for Arab art led to the initiative made by the Austro-Hungarian architect August Salzmann in 1869 proposing the oundation of a museum of Arab art in the mosque of Al-Zaher Bibars at Al-Hussayneya district, which was approved by Khedive Ismail; however, it was not carried out during his rule. ${ }^{74}$ In 1874, the former British consul in Egypt, E. T. Rogers proposed

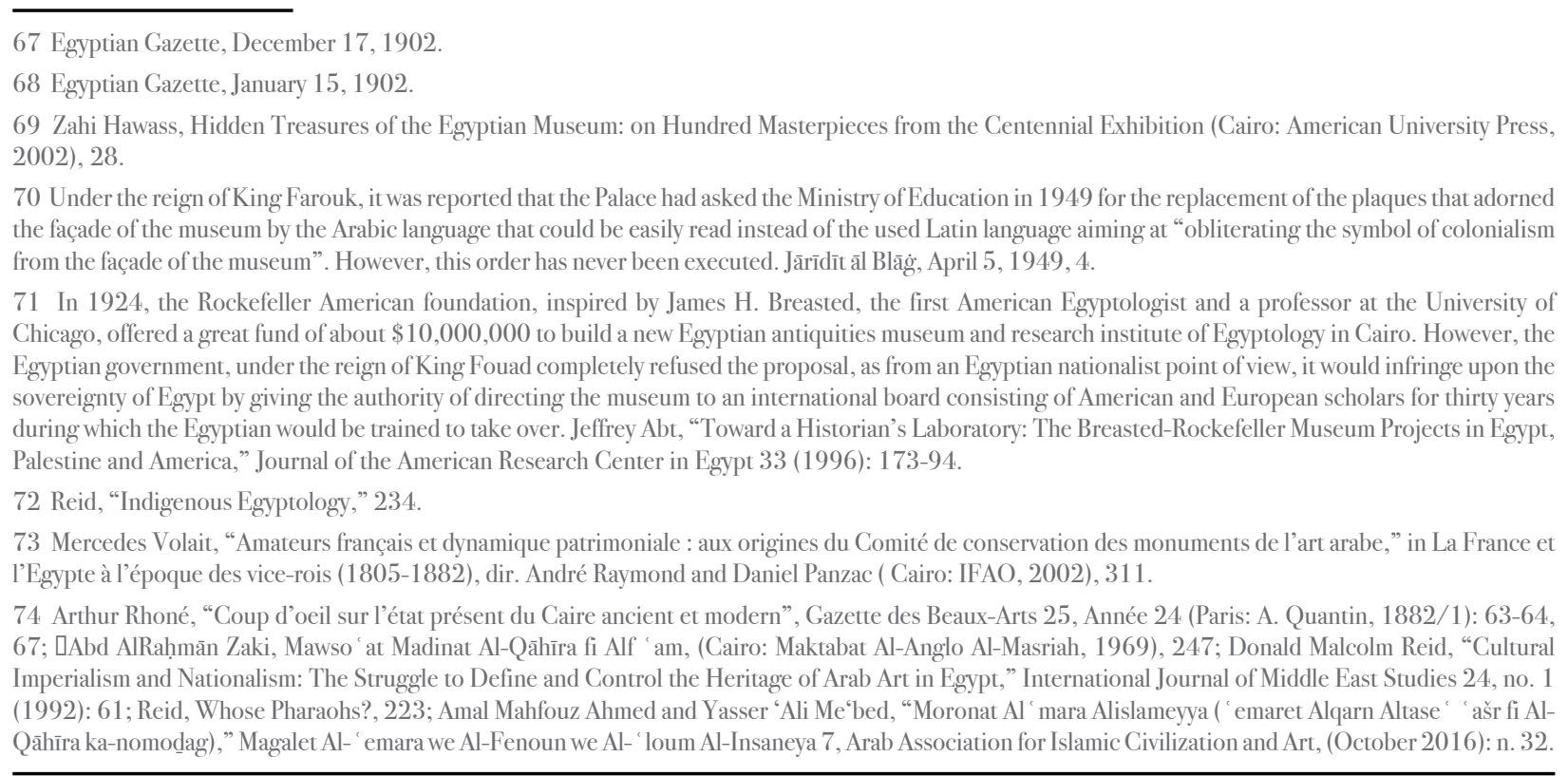

establishinga committee for the preservation of the monuments of Arab art in the Second International Congress of Orientalists held in London, but it did not receive any support neither from Great Britain nor from Egypt. ${ }^{75}$ In 1880 , the nucleus of the Arab museum finally emerged when Khedive Tawfiq ordered the Ministry of Awqaf to collect the monuments of Arab art found in mosques and archaeological sites dating to the period until the mid-1 $19^{\text {th }}$ century in one place. The task of selecting the place had been assigned to Franz, the Hungarian Head of Technical Section of the Waqf Administration, who chose the eastern Iwan of the Mosque of El-Hakem for this purpose. ${ }^{76}$ However, the true creation of the museum was in December 1881 with the so desperate being so clspering the smal and three Furopean ${ }^{78}$ with the principal task being to a me an

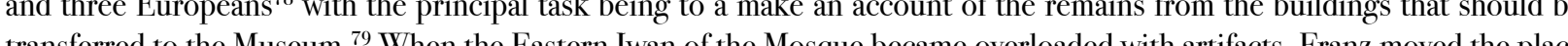
the place of the museum to a temporary building in the courtyard of he same mosque in 1883," which opened in 1884; yet this location the Comité designed in A and was inaugurated in $1903 .{ }^{\circ}$ This new building then was still known as "Museum of Arab Art"; it was renamed "Museum of

\section{- The Graeco-Roman Museum}

Alexandria, which remained a capital in the ancient times for nearly a millennium, undoubtedly needed a museum symbolizing its identity and displaying its antiquities that were scattered in many places or possessed by private collectors. The concept of creating an entity concerned with studying archaeology can be traced back to 1835 upon establishing the "Oriental Society", which was shorly dissolved in favor of a more effective body-yet still with limited benefit- that is the "Egyptian Society", whose mas established for the purposes of documention, research and most importantly for collecting the discovered Entiptien

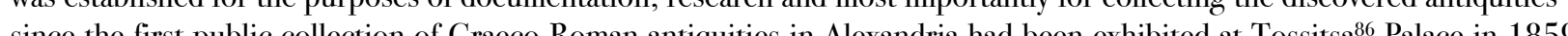
since the firt need of fo that had gathered the British Consul, Sir Charles Cookson, the Italian Archaeologist, Giuseppe Botti together with the Oxford

\footnotetext{
Volatt, Amateurs trançals et dynamique patrimoniale, 320; Reid, Whose Pharaohis?, 223.

76 Zaki, Mawso at Madinat Al-Q̨ăhira, 247.

77 Jean-Gabriel Leturcq, Inventing Islamic Art (3). The Museum of Arab Art in Cairo, 2014, https://leturcq.wordpress.com/2014/01/25/inventingislamic-art-3/.

78 Reid, "Cultural Imperialism and Nationalism," 61; id., Whose Pharaohs?, 22:

79 Comité de Conservation de Monuments del 'Art Arabe, Fasc. 1, exercise 1882-1883, 1892,p. 9, https://www.persee.fr/doc/ccmaa_1110-6824_1892_

80 Max Herz and Stanely Lane-Poole, Catalogue of the National Museum of Arab Art (London: Andesite Press, 1896), x; Zaki, Mawso at Madinat Al-Qähirir

81 Reid, Whose Pharaohs?, 237.

82 Karl Baedeker, Egypt and the Sudan. Handbook for Travellers, 7th edition. (London: T. Fisher Unwin, 1914), 62.

83 Bernard O'Kane, The Illustrated Guide to the Museum of Ilamic Art in Cairo (Cairo the American University in Cairo Press, 2012), 9-10.

84 The term "Islamic" replaced "Arab" in Cairo University in 1933 when Creswell established a program there termed Islamic Archaeology; despite this Egypt: Archaeologies, Museums and the Struggole for Identities from World War I to Nasser, (Cairo: the American University in Cairo Press, 2012), 170. 85 https://asalex.org/history.html Greece upon the death of Mohamed Ali. Najat Abdulhaq, Jewish and Greek Communities in Egypt: Entrepreneurship and Business before Nasser (LondonI.B. Tauris, 2016), 70; Pandelis Michalis Glavanis, "Aspects of the Economic and Social History of the Greek Community in Alexandria during the Nineteent

87 Kyriakos Savvopoulos and Robert Steven Bianchi, "Alexandrian Sculpture in the Graeco-Roman Museum," Graeco-Roman Museum Series 1. The 88 G. Botti, Catalogue des monuments exposés au musée Gréco-romain d’Alexandrie (Alexandrie: Imprimerie Generale A. Moures \& C. 1900), III.
} 
Educator and Assyriologist who developed interest in Egyptology, Rev. Archibald Henry Sayce. ${ }^{89}$ The result was founding a modest museum consisting only of five rooms in two floors at Rossetta Street (Al-Hourreva Avenue Now) in a Kevorks s Building through the cooperation between Alexandria Municipality and the Egyptian Antiquities Service; ${ }^{90}$ it was officially inaugurated by Khedive Abbas Helmy II on the $17^{\text {th }}$ of October $1892 . .^{91}$ Three years later, the current museum building consisting of 10 halls had been established behind Alexandria Municipality through the efforts of its designers, M. M. Dietrich and Leon Stienon, to house the constantly increasing collections; ${ }^{92}$ its façade was designed in a neo-classical style with six columns and pediment top inscribed with the word MOY $\Sigma$ EION. ${ }^{93}$ It was inaugurated in July 1895 by Khedive Abbas Helmy II in the presence of Mokhtar Pasha Ghazi, the High Ottoman Commissary, and consuls from several countries. Several Alexandrian private collectors donated their collections to the museum such as Antoniadis and Zizinia.. ${ }^{94}$ In 1896, two other halls were added; then it was further enlarged in 1899 to include a total of 16 Halls. In 1904 , the number of halls increased to 22.

\section{- The Coptic Museum}

This Museum was the last of the four main antiquities museums to be established, representing the missing link between the Graeco-Roman period and the Islamic era. The idea of collecting Coptic objects started in the mid-19 $9^{\text {th }}$ century when Mariette was primarily sent by the French government to buy Coptic manuscripts for the Louvre before turning his attention to the excavations in Pharaonic sites, ${ }^{6}$ as previously mentioned. In $1880 \mathrm{~s}$ - $1890 \mathrm{~s}$, several studies were made on Coptic language and literature; however the earliest work that raised the awareness of Coptic art and architecture was the publication of Ancient Coptic Churches of Egypt in 1884 by the Oxford Classicist A. J. Butler. ${ }^{97}$ The French Egyptologist and Coptologist, Émile Amélineau, who joined the French Archaeology Mission in Cairo in $1882 .{ }^{98}$ was the first to promote for the idea of preserving the scattered Coptic antiquities in a private museum. ${ }^{99}$ As a result, the Coptic monuments were put under the control of the Comité de Conservation de bArt Arabe in 1896. ${ }^{\circ}$ In December 1897 , the Hungarian architect, Max Herz proposed to the Comite the foundation of a museum for Coptic antiquities after the Patriarchs approval. The Comité commissioned Hussein Pakria Church by Nakhla Al-Baraty Bey 102 (Overseer of the Church); yet it was more like a storage area. At the very beginning of the

\footnotetext{
39 Archibald Henry Sayce, Reminiscenes (London: Macmillan, 1923), 274-75. For information about Sayce, see Roshunda Lashae Belton, A non-traditional
rraditionalist: Rev. A. H. Sayce and his intellectual approach to biblical authenticity and biblical history in late-Victorian Britain (PhD diss., Louisiana Tech

90 Mervat Seif El-Din, “The Greco-Roman Museum of Alexandria. Past, Present, and Future," Bibliotheca Alexandrina. Alex Med Newsletter 20 (August-

1 Botti, Catalogue des monuments exposés, VIIII.

92 Evaristo Breccia, Alexandrea ad Aegyptum. A Guide to the Ancient and Modern Town, and to its Graeco-Roman Museum (Bergamo: Istituto Italiano D’Ari

93 Jean-Yves Empereur, A Short Guide to the Graeco-Roman Museum. Alexandria (Alexandria: Serapis, 1995), 1

94 Seif El-Din, "The Greco-Roman Museum," 7. Worthy of note is that more than one third of the European population by the end of the 19th century and the tors. Gie was a physicician called Tassos Démétrios Néroutsos more notable as collector is is Sir John Antoniadis ( $(1818-1895)$. He left his place of origin, Chios, an island in the Aegean Sea and sertled in Alexandria in 1833 Destablish an estate of his own. He had established his palace and gardens assisted by a Greek architect and two Belgian landscapers who modeled the gardens dating to the 17th century. Reid, Whose Pharaohs?, 149-5

95 Breccia, Alexandrea ad Aegyptum, 121. For six decades since its establishment, the museum's directors were Italians: the first is Giuseppe Botti (1892-
1903 ) who published the first catalogue of the museum in 1893; then came Evaristo Breccia (1903-1931) who made some changes in the exhibition of the Juring the period of World War Il. The museum was closed for renovation in 1984 when more rooms were added for example, the Numismatcic and Jewellery haraohs? 161

96 Brian Fagan, Archaeologists: Explorers of the Human Past (New York: Oxford University Press, 2003), 58.

97 Reid, Whose Pharaohs?, 268

98 Aziz S. 'Ativa, The Coptic Fncyclopedial (USA: Macmillan Press, 1991), 11'

99 Wadí Hanna, Morshed Al-Mătiff Al-Oebti we Kana’es Misr Al-Oadeema we Al-Hesn Al-Romany (Cairo: Al-Matbáa Al-Masrivah El-Ahlia, 1931). 7 .

100 Peter Shechan Pablen

101 Comité de Conservation des Monuments de l'Art Arabe. Fasce. 15, exercice 1898. (Cairo, 1900), 4-6.

102 István Ormos, Max Herz Pasha (1856-1919): His Life and Career, Études Urbaines 6/2, (Cairo: IFAO, 2009): 334, 336
}

20th century, Maspero allocated a room in the Egyptian Museum for Coptic antiquities: ${ }^{103}$ this was the first public display for artifacts dating to that era. Under the frame of releasing the Egyptian Museumss Catalogue Général, the volume Koptische Kunst was published in 1904 by Joser Strzygowski." Apart fron all the previous efforts, the real birth of the Coptic Museun Coptic wan C. 1803 , but he in 1883, but he soon developed a passin 108 and two years later he manged to convince the Patriarch. Cyril V to found the Coptic Museum ${ }^{109} \mathrm{H}$ made the perfect selection for the by the oldest Europeans r being under the Europen hegemony as Simaika was he first Feyptin to foud and direct a museum. Another exception peint is that this point is that his museum belonged to a religious community, possessed by the Coptic Patriarchy rather than to the state for

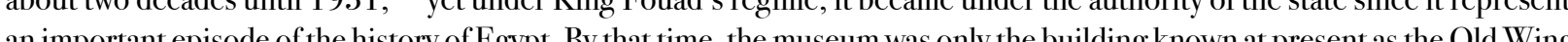
In 1947, alarger new wing was inaugurated. ${ }^{112}$

\section{- Regional Museums}

After a while, when the museums in Cairo became over crowded with antiquities, the idea of establishing regional museum in Egypt was initiated by the Egyptologist Ahmed Pasha Kamal in 1910;113 and together with Maspero, they urged the local authorities to establish small regional Assiut, Aswan, Al-Menya and Tanta.

\section{Assiut Museum}

It was founded in 1912 by El-Sayed Pasha Khashaba, ${ }^{115}$ who was the first Egyptian to get permission for archaeological digs under the supervision of Ahmed Pasha Kamal. The museum was a miniature copy of the Egyptian Museum. It existed until the early 1960 s and is now replaced by Al-Shaimaa Tower and its surroundings at Al-Mahatta Square. ${ }^{116}$

\section{Aswan Museum}

This museum was founded by the Ministry of Public Works in 1913 in Elephantine Island in the residence of the chief engineer of Aswan Dam, which itself was built in 1902. The building was extended towards the east. It included the antiquities from the

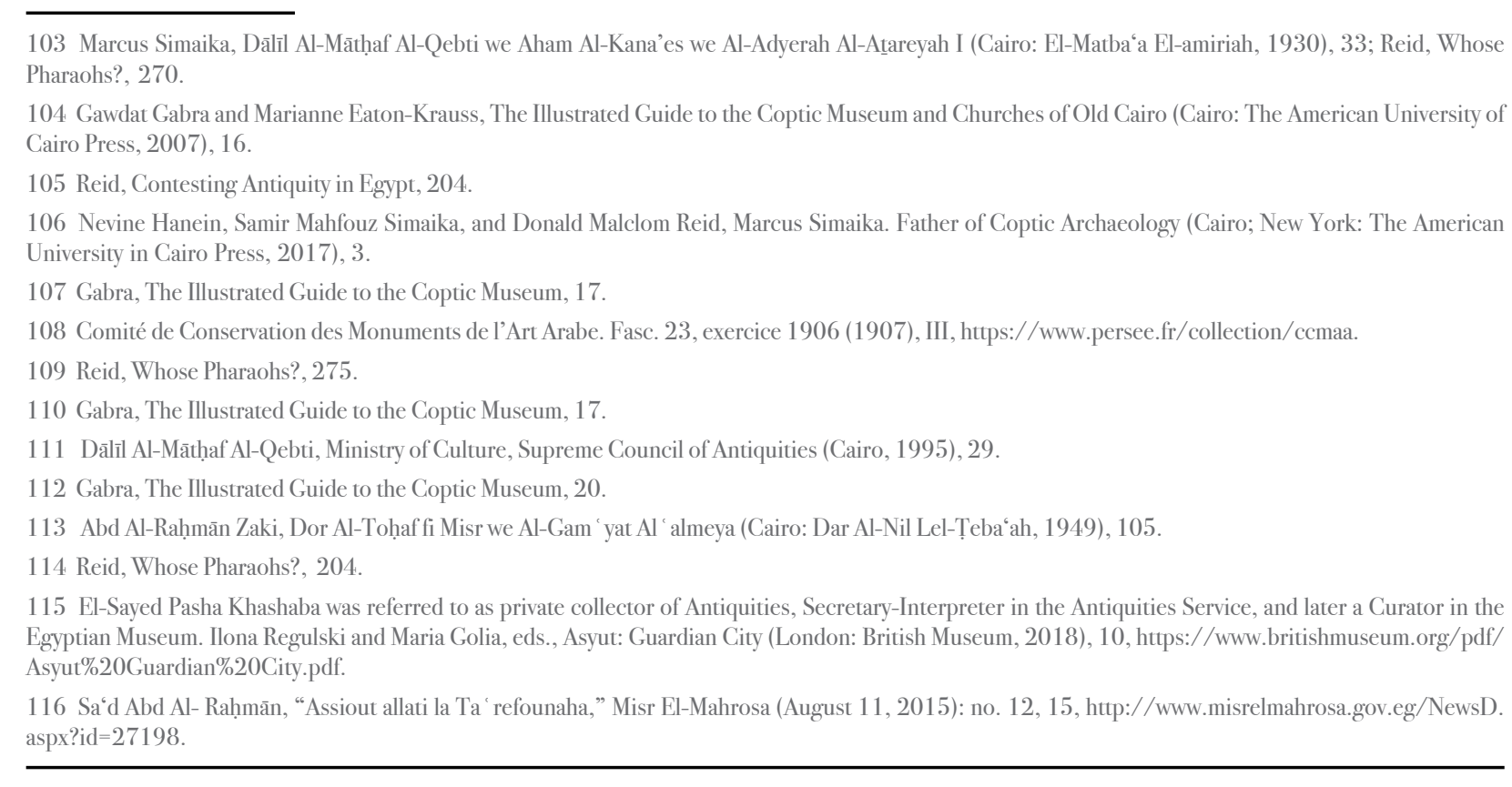


ealy excavations in Elephantine as well as the excavations of Lower Nubia horty before the construction of the Dam.117

\section{Al-Menya Museum}

The Municipality of El-Menya had taken the decision to establish its own museum in 1913; however, it was opened to the public in Marc 1919. It consisted of four rooms and a hall including the antiquities found in the course of raising the height of Aswan Damforthefirsttime. ${ }^{18}$

\section{Tanta Museum}

Also, the Municipality of Tanta, by its turn, had established its local museum in $1913 .{ }^{.19}$ It was provided by collections from Dar Al-Athâr Al-Masreya (The Egyptian Museum) and Dar Al-Athar Al-Arabiya (Museum of Arab Art). ${ }^{120}$ It was closed in 1932; the ancient Egyptian artifacts were put in storage while the Islamic collection was returned to the Museum of Islamic Art. In 1935, the museum was re-founded as recommended by the Ministry ofPublic Education. ${ }^{12}$

\section{- Ethnographic Museum(s) of the Khedival Geographical Society ${ }^{122}$}

Apart from the archaeological museums, Khedival Egypt witnessed the foundation of other types of museums that reflected the cultural discourse of that time. As Khedive Ismail was eager to represent himself as an enlightened ruler and to show that Egypt was following the civilized Western nations, he ordered the foundation of the Egyptian Geographical Society in $1875^{123}$ on the occasion of convening the second International Geographical Congress in Paris. Under the reign of Khedive Abbas Helmy II, a museum was set up in a hall inside the Society headquarter in an Italian school in December $1898,{ }^{124}$ based on the collection (spears, bows, arrows, and shields) brought by the Egyptian Army upon returning back from the Sudan and by Egyptian travelers and discoverers of the Nile sources (costumes, jewelry, toys, and weapons) from the heart of Africa. After 1898, the Society with its museum moved to a special building in the Ministry of Public Works. As it became prominent once more under the reign of King Fouad, so its Museum, publicly known as the Ethnographic Museum/Museums of the Khedival Geographical Society, was officially inaugurated by the King himself on $3^{\text {rd }}$ of April 1925 on the occasion of the celebration of the $50^{\text {th }}$ anniversary of the creation of the EGS. The Museum consists of two floors having two wings; the ground floor is allocated to the Ethnographic Museum/Hall, Africa Hall, and Suez Canal Hall ${ }^{125}$ In 1928, the Society enlarged the museum collection through accepting gifts and buying valuable archaeological and geographical artifacts related to the traditions and customs of the urban and rural Egyptians.

\section{- Irrigation Museum/Museum of Delta Barrages}

Egypt also witnessed the foundation of the Irrigation Museum/ Museum of Delta Barrages in 1900 in the middle of the gardens of Qanater Al-Khayrivah on the occasion of the construction of the submerged weirs behind the Delta Barrages, which was a part

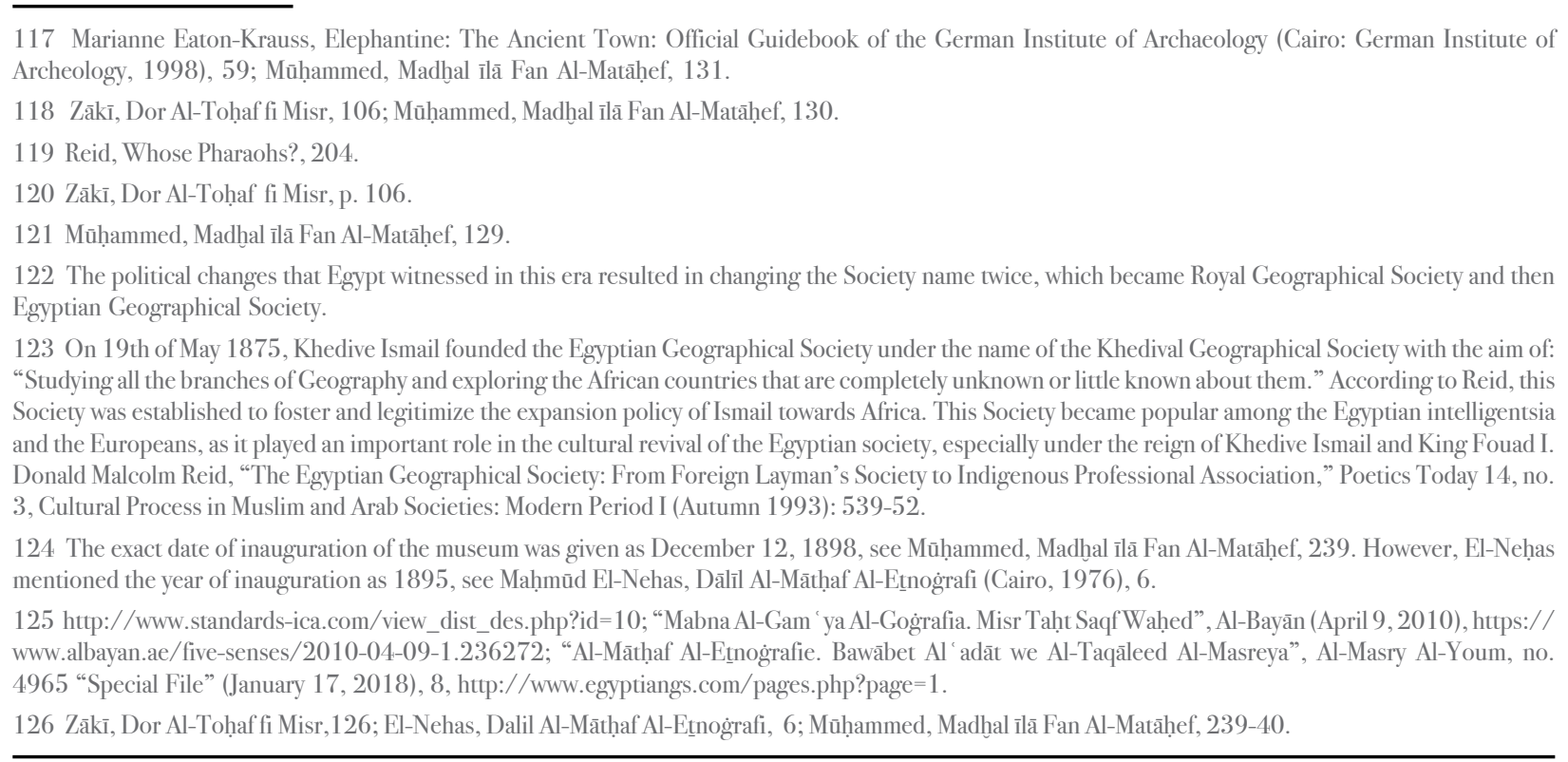

of a gigantic project for improving the irrigation system in Egypt under the British occupation. ${ }^{127}$ The idea for this museum was initiated earlier during the reign of Mohamed Ali when he ordered the establishment of a museum to celebrate the foundatio of the Dela Bur irrigation and drainage works in Egypt and Siln

\section{- Geological Museum}

As a part of the Egyptian Geological Survey that was established earlier under the rule of Khedive Abbas Helmy II in 1896, ${ }^{130}$ the Geological Museum was established in the gardens of the Ministry of Public Works in downtown Cairo and inaugurated in 1904. ${ }^{131}$ The building ${ }^{132}$ consisted of two floors; all of its exhibits had been collected by the teams of the Geological Surve including minerals, rocks, invertebrate and vertebrate fossils. ${ }^{133}$ Worthy of mention is that the first collection to be displayed in the museum was the Fayum Vertebrate Fossils that is the large horned mammal known as Arsinoitherium Zitteli unearthed in 1898 and was sent to London for identification before returning back for display. ${ }^{134}$ The museum has a library with a large collection exceeding 11.000 books and periodicals including original rare books versions. ${ }^{13}$

\section{- Animal Museum in Giza Zoological Garden}

In 1906, after the official inauguration of the first public zoo ${ }^{136} \mathrm{in}$ Egypt, a new museum was established in Giza Zoological garden known by "Animal Museum" for entertainment, educational and research purposes. ${ }^{137}$ In 1920 , a special building was

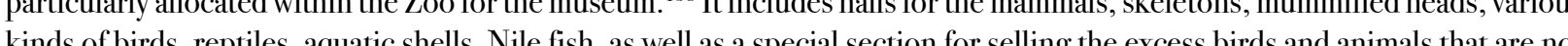

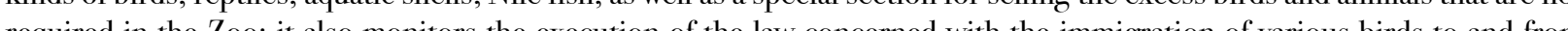
required in the Zoo; it also monitors the execution of the law concerned with the immigration of various birds to and from
Fog

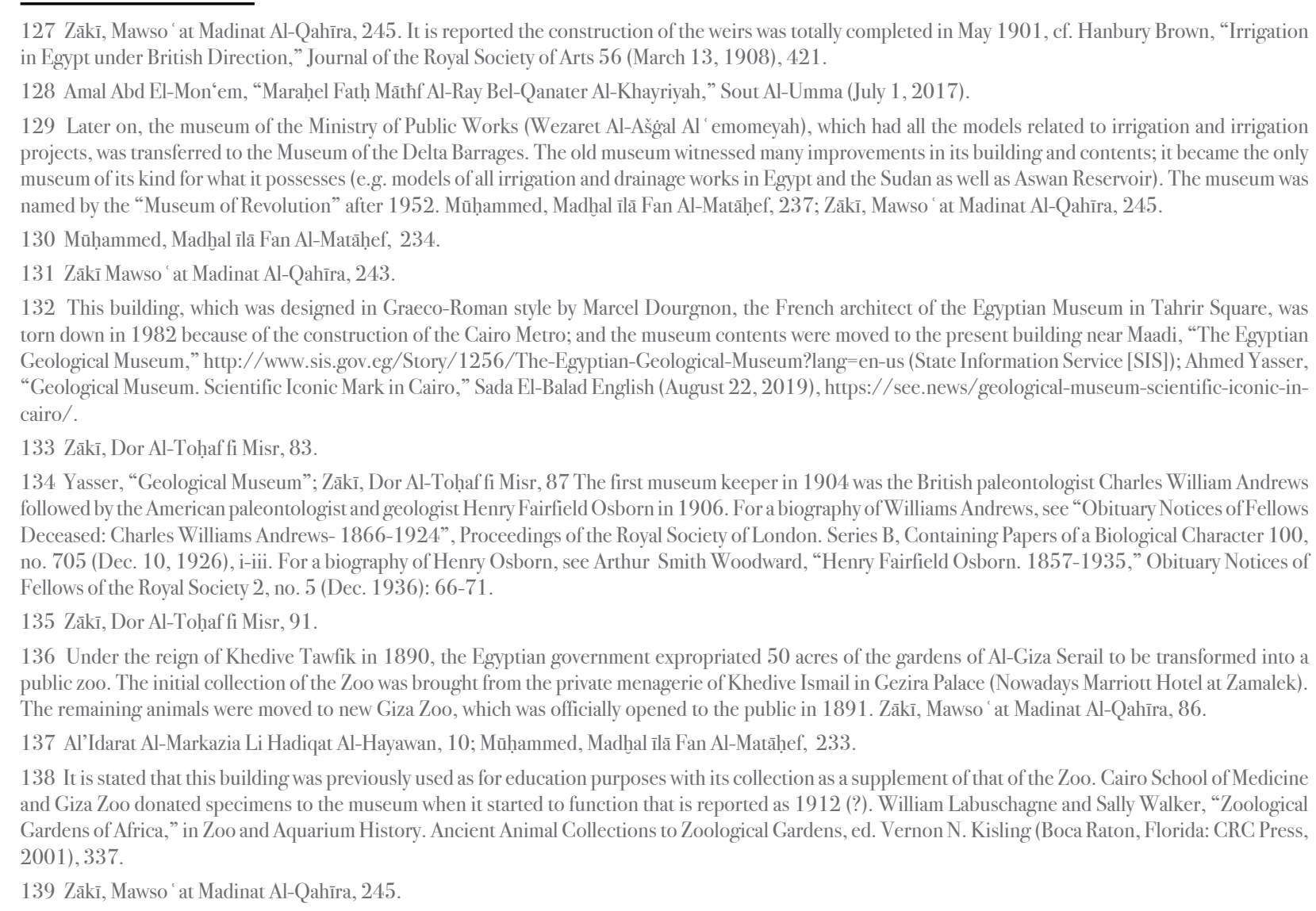




\section{Museums under the Monarchy}

Realizing the fact that museum was a token of modernity and it had the potential of being a reflection of the country national pride and its scientific and cultural development, King Fouad ${ }^{140}$ (r. 1917-1936, Sultan until 1922) sponsored the foundation of several museums throughout Egypt. In the wave of the revolution of 1919 and the British Unliteral Declaration of partial independence in 1922, Egypt had won enough autonomy to challenge the European domination over its cultural institutions. Accordingly, King Fouad tried to retrieve hegemony over the country's heritage from the hands of the foreigners, who had
controlled the museum establishment since the time of Mohamed Ali Pasha, by resuming the studies of Foyptology. He also controlled the museum establishment since the time of Mohamed Ali Pasha, by resuming the studies of Egyptology. He also
sent number of graduated students abroad to study museology and to be trained in the European museums. ${ }^{141}$ On the other hand, he aimed at using the museums as an instrument for securing a place for Mohamed Ali dynasty among the great rulers that reigned Egypt since the dawn of history. So, it can be stated that his reign ushered in a new era for the creation of several new types of muse ums apart from the classic antiquities museums. King Fouad was called by the "Father of the Egyptian Nationalist Museology" because of the construction of numerous museums under his patronage. ${ }^{122}$ Europeans also identified him by "Maecenas", the famous Roman patron of letters under the reign of Emperor Augustus. ${ }^{143}$

\section{- Abdeen Palace Museums}

Following the European royal palaces practice of having museums within the royal residence like Kensington Palace of London, the magnificent Palace of Versalles of Paris and Wilanów Palace in Poland ${ }^{14}{ }^{14} \mathrm{King}$ Fouad gave orders for setting aside some of Abdeen Palace rooms, located on the eastern side in front of Paris gate, for a permanent museum gallery. As Fouad contended that the exhibition of the royal family collection was a symbol of royal authority, therefore, the Palace housed two museums within its walls under his reign: one dedicated for the exhibition of weapons and munitions, and the other one for medals, decorations and precious artilacts. These objects were either inherited among Mohamed Ali's family, or gifts from kings and presidents of the world to the King or bought from international auctions. His successor, King Farouk (r. 1936-1952), provided the museums with many orher objects, especially different and precions Kinds of weapons, as he was famed as one of he world's greatest collectors of weapons and artifacts. He also augmented it with a library specialized in resources related to
warandweapons ${ }^{145}$

\section{- Museum of Prince Mohamed Ali’s Palace}

The practice of having a museum within the royal palaces was not only limited to the main palaces of the kings of Egypt, but it extended to the private residence of the princes of the royal family. Among these famous palaces was the Palace of Prince Mohamed Ali in Manial Al-Rhodah Island. In 1938, Prince Mohammed Ali, the younger brother of Khedive Abbas Helmy II and the cousin of King Farouk, commissioned the construction of a special separate building within his great complex to function as a museum for the exhibition and preservation of about 1200 artifacts of his great collection. Located at the southeast side of the palace, this building has an open courtyard in the center that is surrounded by 15 halls, each hall is dedicated for the exhibition of particular collection. To commemorate his name, Prince Mohamed Ali revealed his intention to Prime Minister, Tawfik Nessim, for turning his palace and his newly-added private museum into a museum accessible to the public as well as the garden of the palace into a public park after his death. ${ }^{14}$

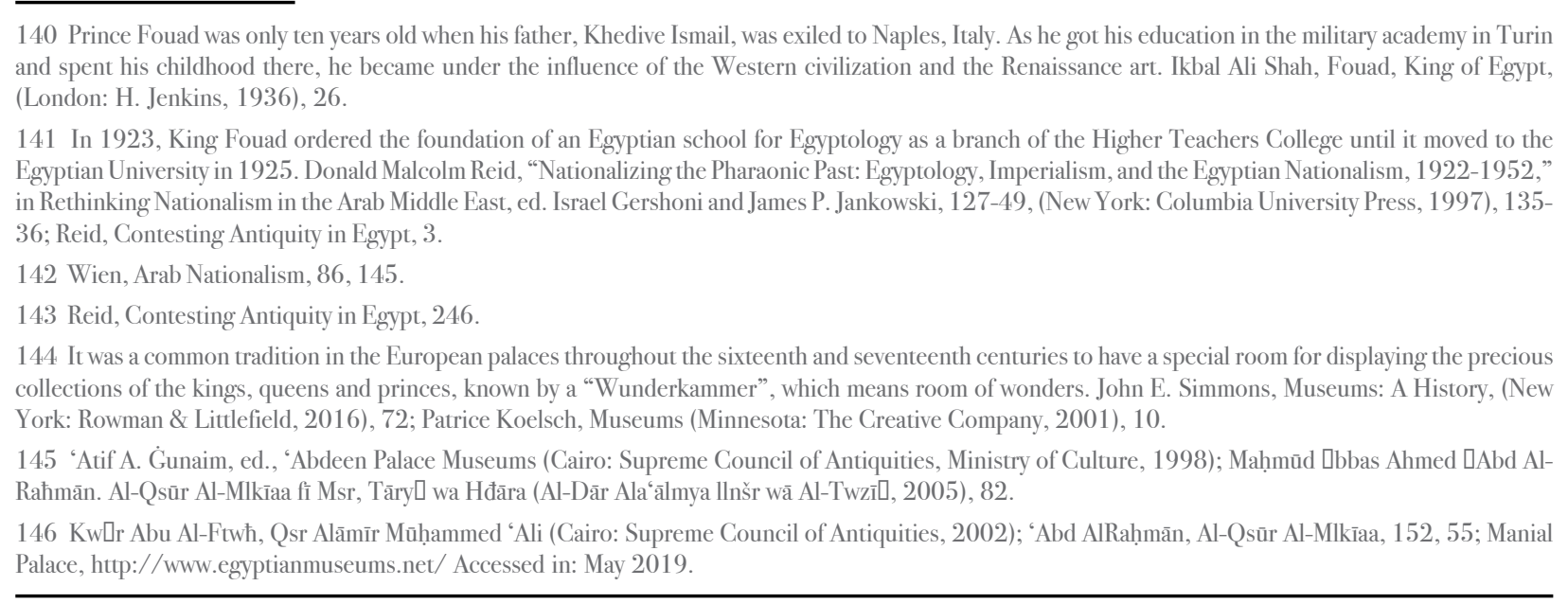

\section{- Museum of Prince YoussefKamal's Palace}

The magnificent palace of Prince Youssef Kamal, the grandson of Ibrahim Pasha and an enthusiastic patron of arts, in Matariah east of Cairo, ${ }^{147}$ also comprised a museum for the exhibition of his rare artistic collection and mummified animals that hunted by the Prince himself After the revolution of 1952, this pace was converted inte a mueum for mummified animals and it by the Prince himself. After the revolution of 1952, this
now used as headquarter of the desert research center 148

\section{- Agricultural Museum}

Besides the tradition of establishing museums within palaces, the Egyptian royal family also used to transform some of the old palaces into museums. The Giza Palace of Khedive Ismail, as previously mentioned, was the first royal palace to be converted into a national museum. Under King Fouad's reign, many palaces were used as museums. The palace of Princess Fatma, King Fouad's sister, which had been donated earlier by herself to Cairo University in the suburb of Dokki is a good example of such museums. When the University erected its own buildings, the palace was given to the Ministry of Agriculture. Being inspired by the Royal Agricultural Museum during his visit to Budapest, King Fouad ordered the conversion of Princess Fatma's Palace into a museum for tracing the long history of agriculture in Egypt from prehistory to modern time. Subsequently, he hired the Hungarian Director of the museum, Alajos Peikert, to construct a similar one in Egypt to be the second of its kind in the world. ${ }^{149}$ Before the foundation of this museum, the Khedival Agricultural Society (later Royal Agricultural Society) established a small museum under the name of the Cotton Museum, ${ }^{150}$ which became a part of "Fouad I Agricultural Museum" after its opening. Since museums could be used as an instrument for public enlightenment and for making inspiring contributions to the national revival of the state, King Fouad made a declaration to the nation on the occasion of the inauguration of the Agricultural Museum on $26^{\text {th }}$ January 1931, asking the Egyptians with all their different classes to improve Egyptian agriculture. ${ }^{151}$ In 1935, a new building with the same architectural style of the palace was added; in 1937, another building was constructed to house a lecture hall, cinema and library was constructed, so it can be said that the museum became an agricultural culture center under the reign of King Farouk. On the $16^{\text {th }}$ of January 1938, the museum was opened to the public only after King Farouk officially inaugurated it on the occasion of the selection of the museum as a venue to host the $18^{\text {th }}$ International Cotton Congress. ${ }^{152}$

\section{- Military Museum}

In the wave of the construction of national museums in 1930s, the Egyptian government issued a decree for transferring the Military Museum that once occupied the palace of Princess Amina, the mother of Abbas Helmy II, in the suburb of Garden City, to its permanent residence in the haremlik quarter of Mohamed Ali's salace complex in Salah el-Din Citadel after its evacuatio Deg 1929 a the Egyptan of of the Brith op a museums in revisited the idea by submitting a memorandum to the Palace, asking King Farouk to emulate the European military museums

147 This magnificent palace was constructed by the famous Italian architect Antonio Lasciac for around 13 years from 1908 to 1921.

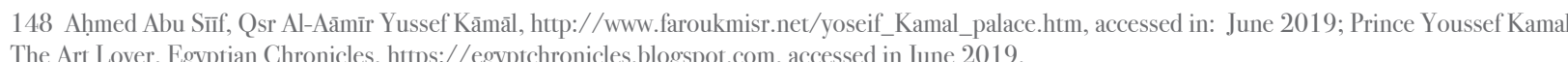

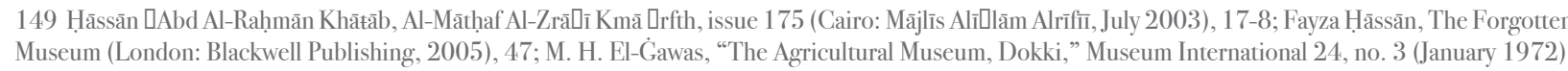
150 As Egypt was famed by its high quality of cotton, the Roval Agricultural Society, which was founded with the aim of improving agricultural and irrigation
methods in Egypt, created a small cotton museum in 1920 in the old agricultural Serail in Gizera. This museum was intitated by Prince Kamal El-Din Hussein, me
the President of the Society. In 1926, on the occasion of the inauguration of the Agricultural-Industrial exhibition, this museum was organized by the the President of the Society. In 1926 , on the occasion of the inauguration of the Agricultural-Industrial exhibition, hils museum was organized by the
Entomologist Mr. Walkies and the Director of the Society Fouad Abaza and it received a lot of visitors. The collection was ultimately related to all phases of cotton cultivation, pests, diseases and process of spinning and weaving, shedd
cotton cultivation and trading. Mühammed, Madhal ilă Fan Al-Matăhef, 229.

151 “Al-Barid Al-Adabi: Al-Mățaf AL-Zira ái Al-Misri," Al-Risala 238, (24 January1938); Wien, Arab Nationalism, 99-10 1522 Khatab, Al-Mâthaf AL-Ziráaia, 17-18; Omnia El Shakry, The Great Social Laboratory: Subjects of Knowledge in Colonial and Postcolonial Egy

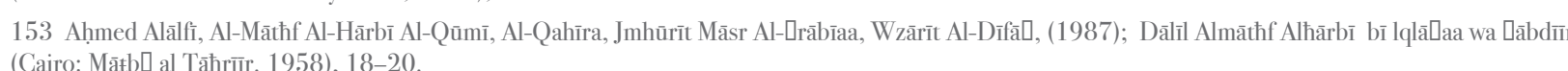


with the aim of referring to the grandeur of the ruling dynasty and its army and of bolstering the civilians' bond with the Egyptian army. Being a man of military principles, King Farouk ordered the refurbishment of the three adjoining interconnected palaces known collectively as Al-Haremlik Palace, which was constructed by Mohamed Ali in 1825 on the western side of the citadel, to accommodate this great museum. The main aim of this museum was to glorify the permanence of Egyptian military prowess since the ancient Egyptian history to modern era. The museum did not merely display objects, but illustrated them in a more easily accessible way, reflecting the longevity of the Egyptian military history and inspired by the military spirit of the oldest army in the world. Accordingly, it can be stated that this museum was the most vocally nationalist museum in Egypt during this period. ${ }^{154}$ On the other hand, choosing palaces to house such museums was an indication that these museums were not hailed only for their comprehensive collections, but also for their outstanding architecture.

\section{- House of the Nation (Museum of Saad Zaghloul)}

In the time that the concept of transforming certain houses into historic museums became in vogue in the United States and in Europe during the $20^{\text {th }}$ century, the emergence of this type of museum in Egypt coincided with the growth of Egyptian nationalism. In 1927, the Liberal Constitutionalist-Wafd coalition cabinet of Abd al-Khaliq Tharwat issued a decree for the conversion of the private residence of Saad Zaghloul the icon of the revolution of 1919 and the founder of Wafad Party-into a national museum as a kind of an honor for him. ${ }^{155}$ The main purpose behind this decree was to use this historic house museum, popularly known as the House of the Nation, as a vehicle to stimulate the national spirit by recounting the story of this national prominent figure through displaying his belongings that were kept in their original places and the house itself, which embodied
the symbolism of Egypt's struggle for independence. ${ }^{156}$

\section{- Museum of Gayer Anderson}

Another example for the private houses that were turned into a museum during this period was the Museum of Gayer Anderson that is located to the southeast corner of the Mosque of Ahmed Ibn Tulun in AL-Sayieda Zeinab. This museum is composed of two old Islamic houses that date back to the sixteenth and seventeenth centuries. In 1935, Major Gayer Anderson, a British physician officer, was authorized by the Egyptian Government to stay in these two houses that were joined together by a bridge at the third-loor level, they became collectively known as Beit a-Krithyya. Inside the house, Anderson arranged his valuable collection of furniture, faience, carpets and other objects that date back to the ancient Egyptian period, Graeco-Roman, Coptic, and slamic eras, as well as other artifacts collected by him from the Near East, in a perfect setting to be displayed to the public. However, in 1942, he was forced to return back to his country because of his ill health. So, he decided to bequeath his precious collection to the Egyptian Government. Subsequently, hhe house with its contents was convercdinto a museum under his name Also, King Farouk bestowed on Anderson the title of Pasha as a gratitude of his kind bequest to the country. ${ }^{157}$

\section{- Railway Museum}

Desiring to show off Egypt's achievements in the field of science and technology and to make them understandable to the public, King Fouad gave orders for the establishment of a railway museum on the occasion that Egypt was celebrating nearly 80 years since the inauguration of its first railway line between Cairo and Alexandria in 1854. King Fouad ordered the completion of the construction of the museum before 1933, the year on which the International Railways Conference would be held in Cairo. Indeed, the museum was opened on $15^{\text {th }}$ of January 1933 to the guests and the members of the conference to be the first of its kind in the region and the second national rail way museum in the world after the British one. The museum, which occupies part of Cairo Railway station, displays hundreds of models of locomotives of every kind, documents, maps of several Egyptian stations and bridges, revealing the evolution of the Egyptian railway. 158

154 Dälil Al-Mătif Al-Härbī, 18; Wien, Arab Nationalism, 145-46.

155 Israel Gershoni and James P. Jankowski, Egypt, Islam and the Arabs: The Search for Egyptian Nationhood, 1900-1930 (New York: Oxford University ress, 1986), 188; Reid, Contesting Antiquity, 30 .

156 Nadia Al-Husseini, ed., Nation's House: Saad Zaghloul Museum (Cairo: Ministry of Culture-Sector of Fine Art-The Central Administration of Technical upport for Museums and Exhibitions), 18

(erson Museum Cairo (Cairo: Ministry of Culture. Supreme Council of Antiquitics, 2003), 3-5.

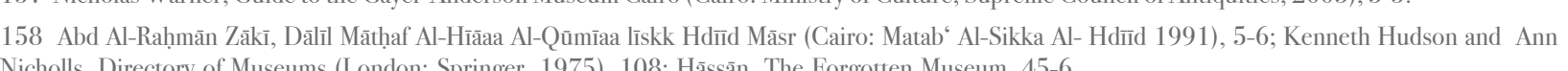

\section{- Postal Museum}

As Egypt was the destination spot for International congresses during this period, ${ }^{159}$ King Fouad also seized the opportunity of holding the tenth Universal Postal Conference in Cairo to establish a Postal Museum at the General Post office in 'Attaba

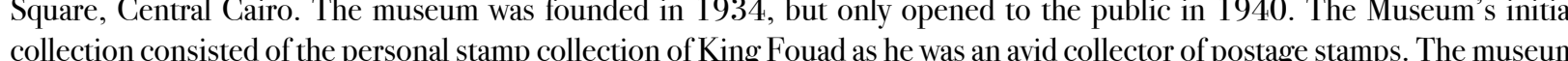
was also intended to demonstrate the development of Foypt's postal services since the Pharaonic period, revealing the wider modernization of the state under Mohamed Ali Pasha and his successors. ${ }^{160}$

\section{- Hygiene Museum}

Realizing the educational role that museums could play in raising awareness among people and that museum could be used as a method of health education, King Fouad directed the Egyptian government to create a museum concerned by giving hygienic advices to the masses of the people. Accordingly, in 1927, the first Hygiene Museum in the entire region was founded in Cairo under the supervision of the Deutsch Hygiene Museum of Dresden in Germany. It was first located in a small building consisted of two floors in Madbouly street in Abdeen, and then it was transferred to Sakakini Palace. The exhibition illustrated the history and techniques of public health, comprising displays of human anatomy, physiology and pathology. Nowadays, it is located in theMinistryofHealth. ${ }^{16}$

\section{- Museum of Modern Art}

In the wake of the cultural revival project under the auspices of King Fouad, the Egyptian government had played a vital role in developing the modern art movement in the country since the 1920's and had funded exhibitions and purchased works of art from Europe. Therefore, in 1927, King Fouad sponsored the foundation of the first Museum of Modern Art in the region A committee, under the supervision of the famous Egyptian sculptor Mahmoud Khalil, was formed to obtain a collection of sculptures and paintings of Egyptian and European artists. The initial collection was purchased by Khali himself together with the Ministry of Education and exhibited in a hall of the Fine Arts Lovers Society in Tigran Pasha Palace in Ibrahim Pasha street (El-Gomhoria Street nowadays). ${ }^{162}$ Then, in 1931, the collection was moved with the new artifacts to the rented Palace of Mousirir ${ }^{103}$ when the museum was officially opened with the exhibition of 584 pieces of art. The expanding collection was then (no

\section{- Wax Museum}

Unlike the public museums that were constructed under the patronage of the Egyptian government during this period, the Wax Museum, established in 1934 by the artist and businessman, Fouad Abd Al-Malik, was a private enterprise for profit. Abd AlMalik, after studying fine arts in Europe and working for a while in the Wax Museum of Paris (Musée Grévin) where he had the

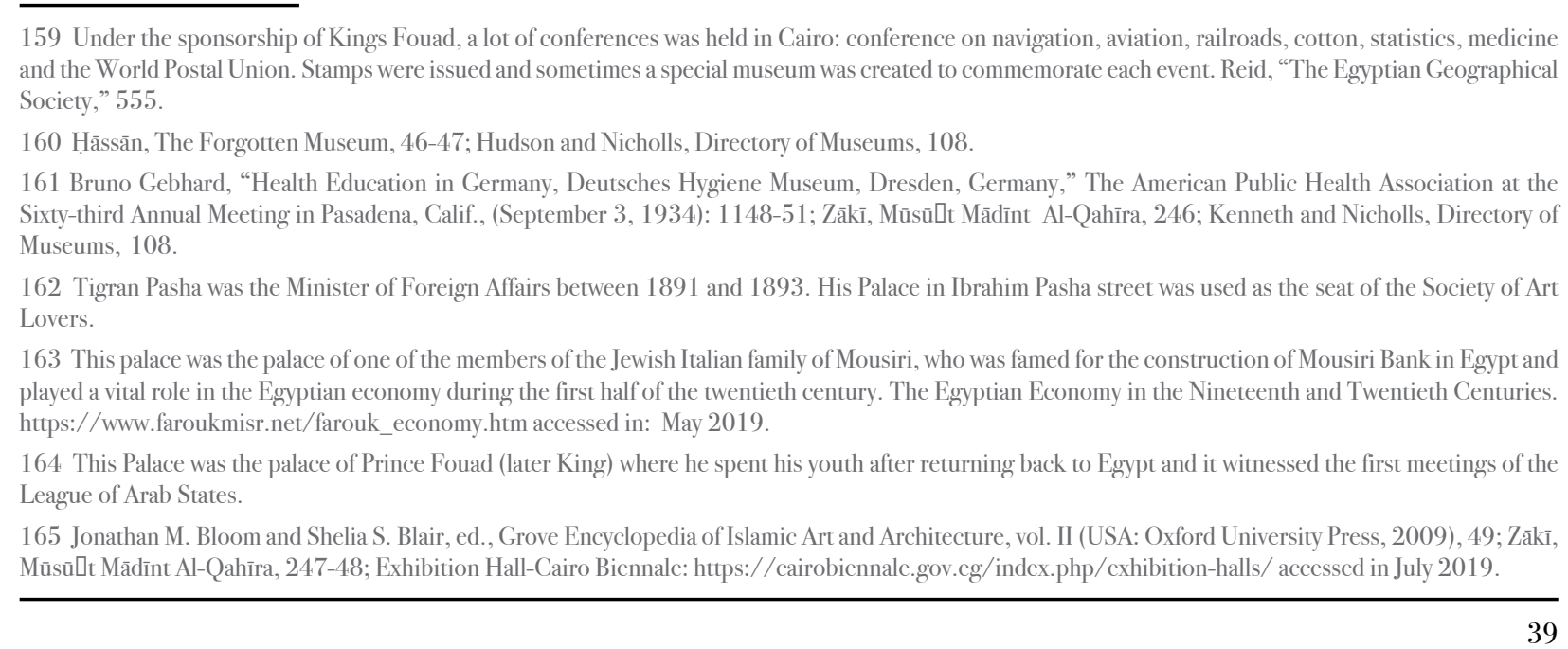


chance to learn the craft, returned back to Egypt in 1919 and set up his own exhibition of wax figures in a rented small gallery in Ismailia Square (nowadays Tahrir Square). Later, he founded his museum in Qasr Al-'Aini street near Garden City, and then filly in Secking to Sech musen depicting the Eyptan hisor fion

who admired the spectacle ofhis museum. ${ }^{167}$

\section{- Museum of Education}

Within the changes in the nationalist and cultural discourses during this period, the Ministry of Public Education became concerned with educating the youth Egypt's past. Hence, in 1929 , museums as an eNedutional instrument, became under the purview of the Ministry of Education instead of the Ministry of Public Works. The Ministry of Education, by its turn, founded of the Islamic historian Ahmed 'Attia Allah. The schools and various scientific organizations had responded to the call of the 列 to clarify the stages of education in Egypt during the last 100 years, to illustrate the history of education in ancient and modern Egypt, and to shed light on the evolution of education and the use of the advanced teaching methods in Egypt. ${ }^{168}$

\section{- Museum of Fouad I's University}

Egypt has known a distinctive type of museums during this period, the university museum, when Fouad I University (Cairo University nowadays) had within its campus a museum to act as a teaching institution for the students of the Institute of Cairo Archaeology at that time. The idea of its establishment was initioted by Professor Zaki Mohamed Hassan, the Dean of the Faculty of Arts in 1943, after Dr. Aly Ibrahim Pasha had bequeathed about 500 pieces of artifacts of carpets, faience, eop the glass, wood, leather and textiles that go back to the Islamic era to the University. As a kind of endorsement to this educational

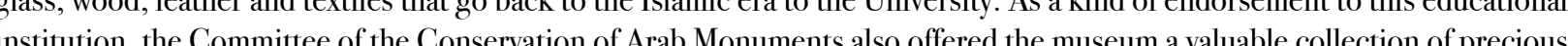
marble stones dating back to the Fatimid, Mamluk and Ottoman periods. ${ }^{169}$

\section{- Port Said Museum}

In addition to the regional museums that were established during the reign of Khedive Abbas Helmy II, the city of Port Said witnessed the foundation of its regional national museum under the monarchy in 1922. Unlike the early regional museums that were established only with the purpose of housing the discovered antiquities in the province, this museum was established to present the development of Egyptian civilization throughout its historical epochs from the early Pharaonic age to the reign of Khedive Ismail, shedding light on the history of the city, as it was a part of the great project of the Suez Canal. ${ }^{170}$ The museum was officially opened in 1923 in a rented house in Sultan Hussein street overlooking the Suez Canal. ${ }^{171}$ Aiming at raising awareness among the masses of the city and attracting local visitors, the museum opened its gate to the public freely on every Tuesday since 1925. From 1927, the museum offered free admission all over the week. In 1947, the museum, being under the supervision of the Antiquities Service like all the other regional museums, exhibited about 735 pieces of artifacts, dating back to the Pharaonic, Graeco-Roman, Coptic, Islamic eras, and Modern Egypt until the end of the reign of Khedive Ismail. 172

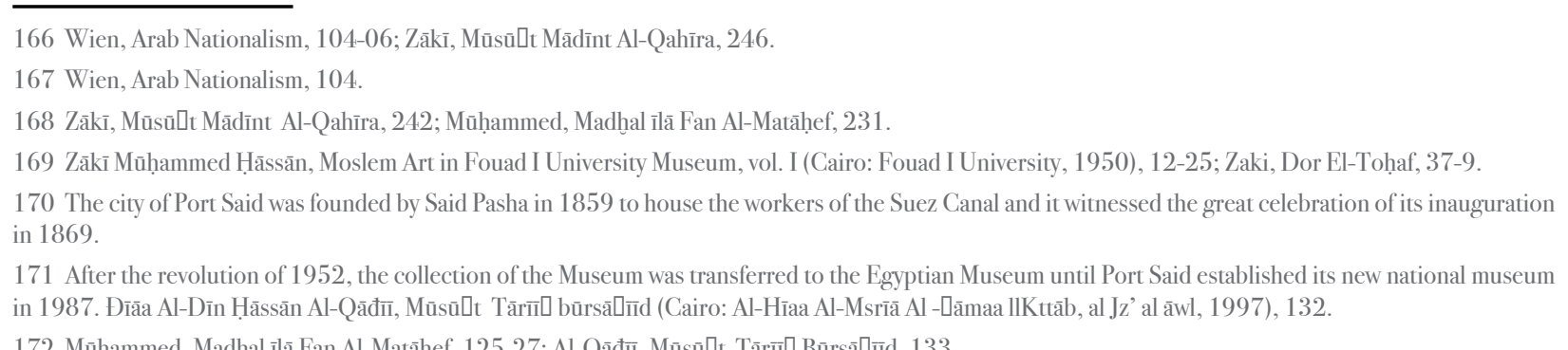
(7)

\section{- Ismailia Museum}

Another regional museum was established in Ismailia in 1934. The initiation for creating a museum there dated back earlier to 1861-1863 when a considerable number of antiquities were discovered during the digging of the sweet water canal, Ismailia Canal. In 1880, these artifacts ${ }^{173}$ were displayed in the Antiquities Square, also known as Ramesses Square or Square Paponot. ${ }^{174}$ Between 1904 and 1914, Jean Clédat, ${ }^{175}$ the Director of Archaeological Excavations, attempted to establish a museum in this place under the auspices of the Compagnie Universalle du Canal Maritime de Suez. ${ }^{176}$ In 1907, the antiquities were moved from Ramesses Square to the old gardens of the Khedive Ismails palace, which was established to receive the monarchs on the occasion of the inauguration of the Suez Canal in 1869. The garden of the palace was called then the "Garden of Antiquities" 177 In 1912, when Clédat asked for the permission of the Antiquities Service to transport number of antiquities to Ismailia, Maspero, as director of the Antiquities Services, replied that nothing will be transported until the Compagnie fulfills its promise Maspero, as director of the Antiquitites Services, replied that nothing will be transported until the Compagnie fulfills its promise
to establish a museum. ${ }^{178}$ In 1914 , several rooms for the small finds were set in a building of the Compagnie located in the Place to establish a museum. In 1914, several rooms for the small finds were set in a building of the Compagnie located in the Place
Champollion -Ismailia's central square- nearby the house of Jean Clédat. In the period from 1914 to 1921, the museum was used for the storage of the furniture of Jean Clédat. In 1928, the museum project was revived by the director of the Compagnie. The Compagnie decided to establish a building replacing the old waterworks to the north of the gardens of Ismails palace. The museum was inaugurated on the $13^{\text {th }}$ of February in 1934, whereas the premises housing the former museum were transformed intotwo schoolsearlierin 1930.179

\section{- Museum of Egyptian Civilization}

The endeavor of King Fouad to repurpose the museums in the direction of Egyptian nationalism was embodied later under the reign of King Farouk in the Museum of Egyptian Civilization, which opened its gates to the public in March 1949. The idea for this museum was developed ten years earlier when King Farouk presented a memorandum to the Royal Agricultural Society that was responsible for the organization of the sixteenth Exhibition for Agriculture and Industry scheduled for 1941. King Farouk, inspired by the Schweizerisches Landesmuseum in Zurich, had asked for forming a committee to study the idea of establishing a big museum for the Egyptian civilization recording the story of Egypt's continuous and unified history from prehistory to the present. Farouk's memorandum, prepared by his Private Secretary, Hussein Hosny Pasha, drew upon a model of a museum tha was relatively different from the traditional Egyptian museums of that time. He aimed at displaying a synthesis of Egypt's history and heritage in a unified and harmonious chronological narrative, challenging the thematic fragmentation of the Egyptian national heritage implied by the four classic museums (Egyptian, Graeco-Roman, Coptic and Arab Art Museums) and by the science and technology museums that had been established under the reign of Abbas Helmy II and Fouad I. ${ }^{180}$ The idea to produce a merge of the dispersed Egyptian museums was an attempt to seize control over Egypt heritage from Europeans hands, who had dominated the main museums for more than a century. Also, it was aimed at promoting an image of Egypt as the product of a longevity old civilization, in which all the Egyptians took part in its glory, representing the Alawiyya Dynasty a

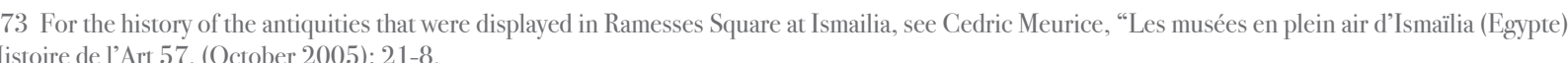

174 Named after Felix Paponot, the chief engineer of Ismailia Canal. Paponot also stated that the antiquities were transported to this square on the expense of the company, see Felix Paponot, L Egypte, son avenir agricole et financier. Notes et document
étude sur les irrigations, (Paris: Librairie Poly Technique Baudry ET Cie, Editeure, 1834) 217 . the Suez Canal Company as well as the Comité de l'Art Arabe and finally left to France in 1914. S. J. Pierre Du Bourguet, "Jean Cledat," in The Coptic

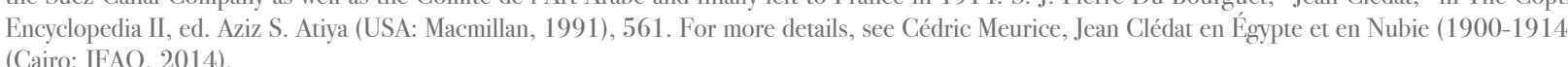

a for a museum. Jean Clédat used to entrust the discoveries to the Service of the domain of the Compagnie Universalle du Can Suez, which manages the findings. Cédric Meurice and Y. Tristant, "Jen 177 In 1907 , the findings reached its peak, especially after the discovery of the sarcophagus sat Tell El-Maskhoutah, and there was no place in the limited square
for the exhibits. Cédric Meurice, "Les musées en plein air d'Ismaililia (Egypte)," Histoire de l'Art 57, (Octobre 2005): 25. For the discovery, see Jean Clédat. "Un couvercle de sarcophage an Thepe

178 Meurice, "Les musées en plein air d'Ismailia," 26

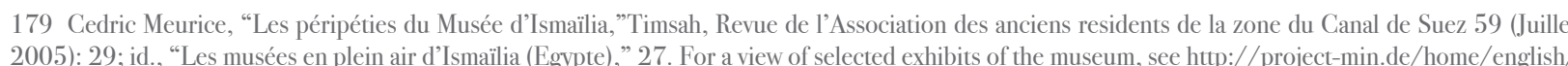

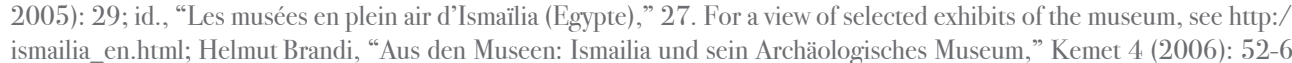

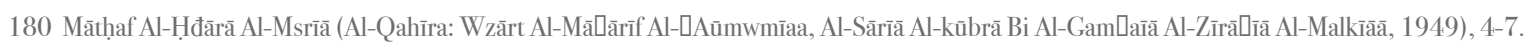


the continuation of this grandeur after Mohamed Ali, the founder of Modern Egypt, restored the splendor of the country after centuries of deterioration and lethargy under Ottoman regime. ${ }^{181}$ Following the general committee meeting, sub-committees were formed from members of the different museums of the country, ${ }^{122}$ including the European directors of the old classic museums and the Egyptian directors of King Fouad's new museums, to deliberate over the themes of the museum exhibits, to review the history and the impact of each era, and to propose topics that the museum should include. These committees were under the supervision of the distinguished modern historian and the Undersecretary of the Ministry of Public Education, Shafiq Ghurbal. Tracking the contextualization that the museum had to follow, it was agreed to divide the museum into several sections, starting by the prehistoric age, then the Pharaonic period that was divided into three thematic subsections narrating the life of the individuals, society and the artistic life in ancient Egypt, then followed by the Graeco-Roman period, Coptic and the Arab Ages. Modern history section was added with four subdivisions: the French Expedition, ${ }^{183}$ Egyptian expansion into the Sudan ${ }^{184}$ dynaty of Mobaned Ali until 1917 focusing on the reign of Mohamed Ali and Khedive Ismail; and finlly, the climactic hall of King Fouad and Farouk.

Following the new trends in the European museums during this period, panoramic paintings, scaled dioramas, stereoscopic maps and models were used to record the customs, tradition, clothing, agriculure, crafts, communications, and conquests all over Egypt's long history It was also decided that skilfil and fam of the exhibition aiming at having a real Eoyptian spirit in the museum. Accordingly, it con be stated that this museum was the outcome of the efforts of different members of the Egyptian museums that joined together to create a museum that would reflect the distinctive Foyption identity ${ }^{185}$ However, the outbreak of the Second World War and budgetary concerns delayed the opening of the musum until 10 February 1949 when King Farouk ingurated it on the occasion of the celcbration of his birthday 186 The news of the in 10 ration of the museum was covered worldwide linking the museum with the resumption of birthday. ${ }^{106}$ The news of the inauguration of the museut was corism “ was located in the grand Serail of the Agricultural Society on Southern Cezira, which is now a part of the new Opera House. After the revolution of 1952 , the museum was left to crumble and decay, until it was decided by the Foyptian government under the rule of former President Hosni Mubarak to revive the idea by constructing a new museum for the Egyptian civilization under the name of the National Museum of Egyptian Civilization in cooperation with the UNESCO near the ruins of Egypt's old capital,Al-Fustat. ${ }^{188}$

\section{Conclusions}

Being the earliest and the most advanced civilization in the ancient world, Egypt was the home for nearly all the branches of knowledge and the source of various methods of education, of which learning within temple was most probably transmitted to Italy and then to Greece through the founders of the earliest school-termed institutions where scholars were centered round Musess shrine, thus reflecting the museum concept. The first museum-termed institution was established in Alexandria during early Ptolemaic Period in Egypt. It was the greatest center of learning in the ancient world, the fame of which - though vanished - is everlasting The Medieval Age lacked museums and witnessed the rise of private collections possessed by Arabs, and late by Europeans. Peculiarly, with the advent of the Renaissance, the museum notion was revived, but in its modern sense, that for the purpose of public display - as was originated - in Italy despite starting with a small number of exhibits. This period is distinguished by the return for such institutions by the Europeans; however, it is only from the mid- $18^{\text {th }}$ century that establishing museums started to spread all over the world. Egypt was not behind to catch up with that new wave; the tradition of founding museums in Eoypt was revived after a long absence of nearly fifteen centuries starting with Al-Antiqakhana at Al-Ezbekiyeh in 1835 . From the mid- $19^{\text {th }}$ century to the first decade of the $20^{\text {th }}$ century, the largest and major four archaeological museums covering the four successive periods starting with the Pharaonic era were established, in addition to other four museums of different types rather than archaeology, which are Ethnography, Geology, Technology and Zoology. The foundation of these types reflects the advancement of museological thought by that time. The increasing flow of antiquities imposed the necessity o establishing regional museums: four in the second decade of the $19^{\text {th }}$ century and other two added later. Under the monarchy, there occurred a change in museums perspective moving beyond collections and collecting to become a place for forging the Egyptian modern national identity. Museums became a part of the scientific and cultural enlightenment project of the Egyptia Kings. Royal patronage of the museums peaked during this period and new different types of museums were established, either to show off the state's achievements in the field of science and technology or to reassert the Palace supremacy. The glorification of the dynasty of Mohamed Ali was the focal point in the historical narrative of most of these new museums. However, as the ancient Egyptian history was an essential component of modern Egyptian identity, the theme of continuity and unity of the Egyptian civilization from Pharaonic Egypt to the rule of Mohamed Ali's dynasty emerged clearly in the storyline of most of the museums that were established during this period specially under the reign of King Farouk. The museum notion has greatly changed from merely housing objects to have a double function, which is display and learning; thus, for the most part returning back to its ancient conception 政 447; Mãțâf Al-Hđđăãă, 15-7-

183 After a long discussion, it was agreed by all the members of the committee that hhe French expedition deserved a separate section, as it marked a turning
point in the history of modern Egypt affer breaking the isolation that imposed on the country for almost three centuries under the Ottoman conquest and it

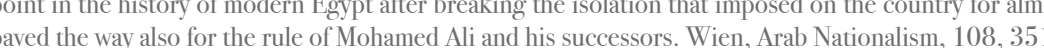

184 As muscum for recording the military, cenonomic and scientific missions sent by the Egyptian rulers in various parts of Africa and to illustrate the perpetual
historical links between Egypt and Sudan from the earliest times to the present era. Wein, Arab Nationalism, 109-13.

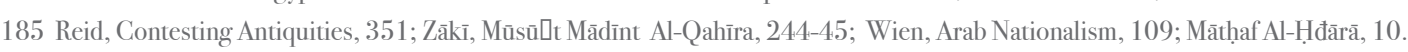

186 Wien, Arab Nationalism, 108, 113-14; Mūhammed, Madhạa ilä Fan Al-Matặef, 182-84

187 New York Times, 10 February 1949, 3; Al-Muqtum, 25 February 1949, 3.

188 Reid, Contesting Antiquities, 352: Wien, Arab Nationalism, 117 


\begin{tabular}{|c|c|c|c|c|c|}
\hline \multicolumn{6}{|c|}{ Classification of Museums in Modern Egypt until 1952} \\
\hline No. & Name & Location & Reign & $\begin{array}{l}\text { Year of } \\
\text { Foundation }\end{array}$ & Type \\
\hline 1 & $\begin{array}{l}\text { Museum of Sheikh Rifáa or Al-Antiqakhana/ Boulaq Museum/ } \\
\text { Giza Museum/Present Egyptian Museum }\end{array}$ & $\begin{array}{l}\text { Ezbekiyeh/Boulaq/ Palace of Khedive Ismail in Giza/Ismailia Square (nowadays } \\
\text { Al-Tahrir Square) }\end{array}$ & $\begin{array}{l}\text { Mohamed Ali Pasha/Said Pasha/ } \\
\text { Khedive Tawfik/Khedive Abbas } \\
\text { Helmy II }\end{array}$ & $\begin{array}{l}1835 / 1858 / \\
1890 / 1897\end{array}$ & Archaeology \\
\hline 2 & Museum of Arab Art (Museum of Islamic Art) & Mosque of El-Hakim/ Bab Al-Khalq, Cairo & Khedive Abbas Helmy II & $1881 / 1898$ & Archaeology \\
\hline 3 & Graeco-Roman Museum & Raml Station, Central Alexandria & Khedive Abbas Helmy II & 1892 & Archaeology \\
\hline 4 & Ethnographic Museum & Al-Qasr Al-'Ani & Khedive Abbas Helmy II & 1895 & Ethnography \\
\hline 5 & Irrigation Museum & Al-Qanater-Al-Khairiyah & Khedive Abbas Helmy II & 1900 & Technology \\
\hline 6 & Geological Museum & Athar Al-Nabi, M'aadi & Khedive Abbas Helmy II & 1901 & Natural History \\
\hline 7 & Animal Museum & Giza Zoological garden & Khedive Abbas Helmy II & 1906 & Natural History \\
\hline 8 & Coptic Museum & Old Cairo & Khedive Abbas Helmy II & 1908 & Archaeology \\
\hline 9 & Assiut Museum & Assiut & Khedive Abbas Helmy II & 1912 & Regional (Archaeology) \\
\hline 10 & Aswan Museum & Aswan & Khedive Abbas Helmy II & 1913 & Regional (Archaeology) \\
\hline 11 & Al-Minya Museum & Al-Minya & Khedive Abbas Helmy II & 1913 & Regional (Archaeology) \\
\hline 12 & Tanta Museum & Tanta & Khedive Abbas Helmy II & 1913 & Regional (Archaeology) \\
\hline 13 & Cotton Museum & El-Dokki & Sultan Fouad & 1920 & Natural History \\
\hline 14 & Private Museum of Prince Youssef Kamal & Palace of Prince Youssef Kamal in Matariah & Sultan Fouad & 1921 & Private Museum \\
\hline 15 & Port Said Museum & Port Said & King Fouad & 1923 & Regional (National) \\
\hline 16 & Abdeen Museums & Abdeen Palace & King Fouad & $\mathrm{N} / \mathrm{A}$ & Military and History Museums \\
\hline 17 & House of the Nation (Beit El-Umma) & House of Saad Zaghloul in Mounira, Cairo & King Fouad & 1927 & Historic House \\
\hline 18 & Hygiene Museum & Ministry of Public Health in Al-QQasr Al-'Ani & King Fouad & 1927 & Science \\
\hline 19 & Modern Art Museum & Gezira Island & King Fouad & 1927 & Art \\
\hline 20 & Agricultural Museum & Palace of Princess Fatma in Dokki & King Fouad & 1931 & History \\
\hline 21 & Railway Museum & Cairo Railway Station & King Fouad & 1933 & Technology \\
\hline 22 & Postal Museum & Central Post Office- Al-'Attaba, Central Cairo & King Fouad & 1934 & Technology \\
\hline 23 & Wax Museum & Helwan & King Fouad & 1934 & History \\
\hline 24 & Ismailia Museum & Ismailia & King Fouad & 1934 & Regional (Archaeology) \\
\hline 25 & Museum of Education & Ministry of Education, El-Falky St., Cairo & King Farouk & 1937 & History \\
\hline 26 & Private Museum of Prince Mohamed Ali & Palace of Prince Mohamed Ali, Manial Rhodah Island & King Farouk & 1938 & Private \\
\hline 27 & Museum of Fouad I University & Fouad I University (Cairo University & King Farouk & 1943 & University Museum \\
\hline 28 & Gayer Anderson Museum & Beit Al-Kerittliyah in Ahmed Ibn Tulun Square, Sayyida Zeinab, Cairo & King Farouk & 1945 & Historic House \\
\hline 29 & Military Museum & Al-Haramlik quarter of Mohamed Ali's complex in Salah el-Din Citadel & King Farouk & 1949 & Military \\
\hline 30 & Museum of Egyptian Civilization & Gezira Island & King Farouk & 1949 & Civilization \\
\hline
\end{tabular}




\section{Bibliography:}

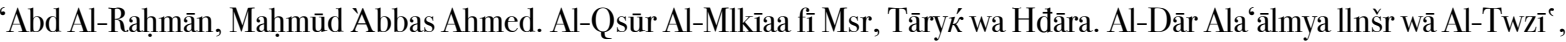
2005

"Abd Al-Rahmān, S'‘d. “Assiout Allati la Ta refo

misrelmahrosa.gov.eg/NewsD.aspx?id=27198.

"Alya, Aziz S. The Coptic Encyclopedia I. USA: Macmillan Press, 1991.

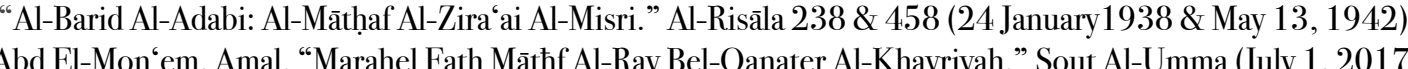

Abdulhaq, Najat. Jewish and Greek Communities in Egypt: Entrepreneurship and Business before Nasser. London: I.B. Tauris, 2016.

Abt, Jeffrey. "Toward a Historian's Laboratory: The Breasted-Rockefeller Museum Projects in Egypt, Palestine and America." Journal of the American Research Center in Egypt 33 (1996): 173-94.

Abt, Jeffry. “The Origins of the Public Library." In A Companion to Museum Studies, edited by Sharon Macdonald 115-34. UK: Blackwell, 2006.

Abu Al-Ftwh, Kwhr. Qșr Al-Amīr Mūhammed ‘Ali. Cairo: Supreme Council of Antiquities, 2002 Abu Sīif, Aћmed. Q Qșr Al-Amīr Yussef Kāmāl, http://www.faroukmisr.net/yoseif_Kamal_palace.htm, accessed in: June 2019.

Ahmed, Amal Mahfouz and Yasser 'Ali M'bed. "Moronat Al- 'mara Al-Islameyya ('emaret Al-Qarn Altase ' 'shr fi Al- AlQahîra ka-Namodag." "Magalet Al- 'Marawe Al-Fenoun we Al- 'loum Al-Insaneya7, Arab Association for Islamic Civilization and Art, no. 32. (October 2016).

Aikin, Roger Cushing. "Romae de Dacia Triumphantis: Roma and Captives at the Capitoline Hill.” The Art Bulletin 62, no. 4 (Dec. 1980): 583-97.

Al-Husseini, Nadia ed. Nation's House: Saad Zaghloul Museum, Cairo: Ministry of Culture-Sector of Fine Art -The Central Administration of Technical Support for Museums and Exhibitions.

"Al-Mãthạ Al-Ețnoğrafie. Bawabet Al- adāt we Al-Taqāleed Al-Masreya", Al-Masry Al-Youm January 17, 2018, http:// www.egyptiangs.com/pages.php?page=1, accessed in: May 2019

Al-Muqttm, February 25, 1949

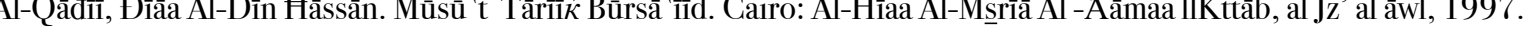
Al-Youzbeky, Tawfik Sultan. “Al-Hadarah Al- 'Arabiya fi Al-Andalus we Ațareha fi Uroba.” Adāb Al-Rafedeen 13, (January 2007): 9-36.

Alıidarat Al-Markazia Lihadiqat Al-Hayawan.

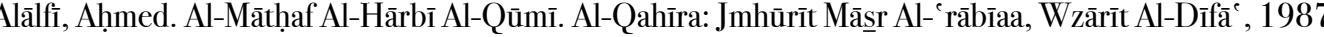

Alexander, Edward P. and Marry Alexander. Museums in Motion. An Introduction to the History and Functions of Museums. Lanham: Altamira Press, 2008.

Aristeas. The Letter of Aristeas to Philocrates.

Baedeker, Karl. Egypt and the Sudan. Handbook for Travellers. $7^{\text {th }}$ edition. London: T. Fisher Unwin, 1914.

Baker, Charles F. and Rosalie F. Baker. Ancient Greeks. Creating the Classical Tradition. Oxford University Press, 1997 Berti, Monica Virgilio Costa. The Ancient Library of Alexandria. A Model for Classical Scholarship in the Age of Million Book Libraries." CLIR Proceedings of the International Symposium on the Scaife Digital Library, 2009. Bloom, Jonathan M. and Sheila S. Blair, ed., Grove Encyclopedia of Islamic Art and Architecture, vol. II. USA: Oxford University Press, 2009.

Botti, G. Catalogue des monuments exposés au musée Gréco-romain d:Alexandrie, Alexandrie: Imprimerie Generale A. Moures \& C., 1900.

Breccia, Evaristo. Alexandrea ad Aegyptum. A Guide to the Ancient and Modern Town, and to its Graeco-Roman Museum. Bergamo: Istituto Italiano D’Art Grafiche,1922.

Budge, E. A. Wallis. Cook's Handbook for Egypt and the Egyptian Sudan. Third edition, London: Thos. Cook \& Son, udgate Circus, E. C, 1911.

Butcher, Samuel Henry. Aristotle. Poetics, Mineola. Mineola, New York: Dover Publications, 1997.

Capart, Jean. "Bulletin critique des religions de l.Egypte 1906 ET 1907." Revue de lhistoire des religions, vol. 59, 909): $160-220$

Casson, Lionel. "II Palazzo dei Conservatori.” Archaeology 25 no. 2 (April 1972): 96-102

Cicero, Marcus Tillius. De Finibus Bonorum et Malorum, Book V.

Clement of Alexandria, Stromata, Book I.

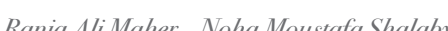

Colla, Elliott. Conflicted Antiquities, Egyptology, Egyptomania, Egyptian Modernity. Durham and London: Duke University Press, 2007.

Comité de Conservation de Monuments de l.Art Arabe, Fasc.1, exercise 1882-1883, 1892, https:/ /www.persee.fr/doc/ C

Comité de Conservation des Monuments de lsArt Arabe. Fasc. 23, exercice 1906, 1907, p. III, https://www.persee.fr collection/ccmaa.

- The Hieroglyphics of Horapollo Nilous. Book II, London: William Pickering, 1840.

Dālîi Al-Māthf Al-Qebti. Cairo: Ministry of Culture, Supreme Council of Antiquities, Cairo, 1995.

.

Di-Capua, Yoav. Gatekeepers of the Arab Past: Historians and History Writing in Twentieth-Century Egypt. Berkeley Dilifornia Press, 2009.

Du Bourguet, Pierre. S. J. “Cledat, Jean.” In The Coptic Encyclopedia I. USA: Maclmillan, 1991

Eaton-Krauss, Marianne. Elephantine: The Ancient Town: Official Guidebook of the German Institute of Archaeology. Cairo: German Institute of Archeology, 1998.

Dyer, George. Poetics: Or, Series of Poems, and Disquisitions on Poetry II. London: J. Johnson and co., 1812.

Egyptian Gazette, December 17, 1902

Egyptian Gazette, January 15, 1902

-Shakry, Omnia. The Great Social Laboratory: Subjects of Knowledge in Colonial and Postcolonial Egypt. California: Cinc

.

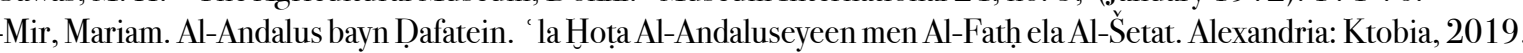

El-Nehas, Mahmūd. Dālil Al-Matḥaf Al-Ețnog̣rafi. Cairo, 1976.

Empereur, Jean-Yves. A Short Guide to the Graeco-Roman Museum. Alexandria. Alexandria: Serapis, 1995.

Erskine, Andrew. "Culture and Power in Ptolemaic Egypt: The Museum and Library of Alexandria." Greece and Rome 42 10. 1, (Apr., 1995): 38-48.

Exhibition Hall-Cairo Biennale: https://cairobiennale.gov.eg/index.php/exhibition-halls, accessed in: Julv 2019 Fagan, Brian. Archaeologists: Explorers of the Human Past. New York: Oxford University Press, 2003

Fortenbaugh, William W and Eckart Schutrumpf ed. Demetrius of Phalerum: Text Translation and Discussion. New Brunswick and London: Transaction Publishers, 2000.

Gabra, Gawdat and Marianne Eaton-Krauss. The Illustrated Guide to the Coptic Museum and Churches of Old Cairo. Cairo: The American University of Cairo Press, 2007.

Gebhard, Bruno."Health Education in Germany, Deutsches Hygiene Museum, Dresden, Germany.” The American Public Health Association at the Sixty-third Annual Meeting in Pasadena, Calif., (September 3, 1934): 1148-1151.

Gershoni, Israel and James P. Jankowski. Egypt, Islam and the Arabs: The Search for Egyptian Nationhood, 1900-1930. New York: Oxford University Press, 1986.

Glavanis, Pandelis Michalis. "Aspects of the Economic and Social History of the Greek Community in Alexandria during the Nineteenth Century." PhD diss., University of Hull, 1989

Greenfield, Jeanette. The Return of Cultural Treasures. London: Cambridge University Press, 1996.

Griffith, F. LL. “The Decipherment of the Hieroglyphs," Journal of Egyptian Archaeology 37, (Dec. 1951), 38-46.

Gunaim, 'Atif A. ed. 'Abdeen Palace Museums. Cairo: Supreme Council of Antiquities, Ministry of Culture, 1998.

Guthrie, William Keith Chambers. A History of Greek Philosophy IV. Plato: The Man and his Dialogues. Earlier Period. UK: Cambridge University Press, 1975.

Haikal, Fayaz. "Egypt's Past Regenerated by its Own People." In Encounters with Ancient Egypt, Consuming Ancient Egypt, edited by Sally MacDonald and Michael Rice, 123-38. California: UCL Press, 2003.

Hanein, Nevine, Samir Mahfouz Simaika and Donald Malclom Reid. Marcus Simaika. Father of Coptic Archaeology. Cairo; New York: The American University in Cairo Press, 2017.

Hanna, Wadi'a. Morshed Al- Mãthaf Al-Qebti we Kana’es Misr Al-Qadeema we Al-Hesn Al-Romany. Cairo: Al-Matba`a Al-Masriyah El-Ahlia, 1931

Hassan, Fayza. The Forgotten Museum. London: Blackwell Publishing, 2005.

Hāassān, Mūhammed “Abd El-Gani. “Men Ḥadaret Al-Islam. Dor Al-Toḥaf Al- 'arabiya.” Al-Risāla 545, (Dec. 13, 1943).

Hậssān, Zaki Mūhammed. Moslem Art in Fouad I University Museum, Vo. I. Cairo: Fouad I University, 1950.

Khater, Antoine. Le Regime Juridique de Fouilles et des Antiquites en Egypte. Cairo: Imprimerie de l' Institute Francais d'Archeologie Orientale, 1960

Hawass, Zahi. Hidden Treasures of the Egyptian Museum: on Hundred Masterpieces from the Centennial Exhibition. 


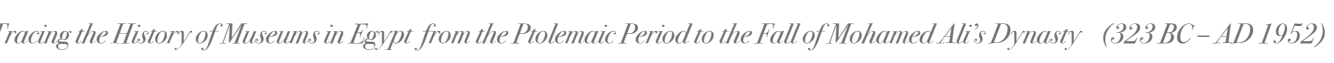

Cairo: The American University Press, 2002.

Heller-Roazen, Daniel. "Traditionss Destruction: On the Library of Alexandria." October 100, Obsolescence (Spring,

, Max and Stanely Lane-Poole. Catalogue of the National Museum of Arab Art. London: Andesite Press, 1896. http://www.standards-ica.com/view_dist_des.php?id=10.

htups://www.faroukmisr.net/farouk _economy.htm, accessed in: May 2019.

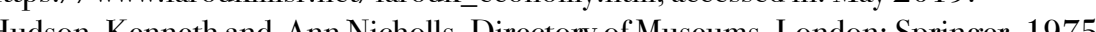

Irenaeus, Against Heresies 3, 21,2

James, Thomas G. H. Excavating in Egypt, The Egypt Exploration Society 1882-1982. London: University of Chicago Press, 1982.

Jārìdit āl Blāğg, April 5, 1949

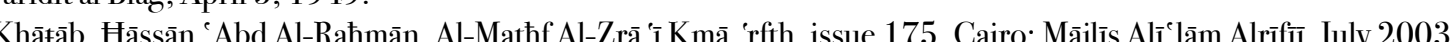

Koelsch, Patrice. Museums. Minnesota: The Creative Company, 2001.

Labuschagne, William and Sally Walker. "Zoological Gardens of Africa." In Zoo and Aquarium History. Ancient Animal Collections to Zoological Cardens, edited by Vernon N Kisling. 331-349. Boce Raton, Florida: CRC Press, 2001. Laertius, Diogenes. Lives of Eminent Philosophers, Book V.

Leao, Delfim. "Plutarch on Demetrius of Phalerum: The Intellectual, the Legislator and the Expatriate." Symposion 2017, Vorträge zur Griechischen und Hellenistischen Rechtsgeschichte, (2018): 441-58.

Lebee, Thomas. "Le musee d'antiquities egyptiennes de Bulaq (1858-1889) Fairs Connaitre et Aimer l'Egypte Ancienne au XIX siècle." Memoire d' etude, 1 annee de 2 cycle (Mai 2013): 1- 53.

Leturce, Jean-Cabriel. Inventing Islamic Art (3). The Museum of Arab Art in Cairo, 2014, https://leturcq.wordpress. com/2014/01/25/inventing-islamic-art-3/, accessed in: May 2019.

Livius, Titus (LivY). The Hist ory of Rome, Book XXXI.

Louca, Anouar. Voyageurs et ecrivains egyptiens en France au XIXe siècle, Etudes de litterature etrangere et compare. Paris: Didier, 1970.

"Mabna Al-Gam 'ya Al-Goğrafia. Misr Taht Saqf Wahed." AlBavan (April 9, 2010), https://www.albavan.ae/fivesenses/2010-04-09-1.236272.

MacLeod, Roy. The Library of Alexandria. Centre of Learning in the Ancient World, Second edition. Cairo: American University of Cairo Press, 2005.

Magdolen, Dušan. "The Development of the Sign of the Ancient Egyptian Goddess Seshat down to the End of the Old Kingdom: Analycis and Interpretation I-II-III" Asian and African Studies 14, no. 2, (2005): 44-55, 196-227; 15, no. 1 , (2006): 55-72.

Magdolen, Dušan. “A New Investigation of the sign of Ancient Egyptian Goddess Seshat.” Asian and African Studies 18, no. 2, (2009): 169-189.

Mahmoud, Shadia. "The Development of Archaeological and Historical Museums in Egypt during the Nineteenth and Twentieth Centuries: Imperialism, Nationalism, UNESCO Patronage, and Egyptian Museology Today.” PhD diss., Texas Tech University, 2012.

Marcellinus, Ammian. Roman History, Book XXII.

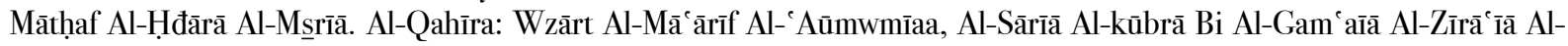
Malkīāâ, 1949

Meurice, Cedric. "Les musées en plein air d.Ismailia (Egypte).” Histoire de l.Art 57, (October 2005): 21-28.

Meurice, Cédric. Jean Clédat en Egypte et en Nubie (1900-1914). Cairo: IFAO, 2014.

Meurice, Cedric. "Les péripéties du Musée d IIsmaillia." Timsah, Revue de l/Association des anciens residents de la zone du Canal de Suez, no. 59, (Juillet 2005): 29-44.

Minchin, Elisabeth. "The Poet Appeals to His Muse. Homeric Invocations in the Context of Epic Performance.” The Classical Journal 91, no.1, (Oct-Nov.1995): 25-33.

Minton, William W. "Homers Invocations of the Muses: Traditional Patterns." Transactions and Proceedings of the American Philological Association 91, (1960): 292-309

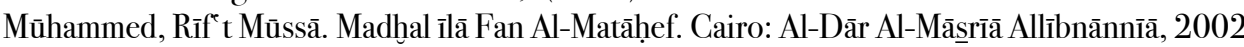

Murray, Tim. Milestones in Archaeology: A Chronological Encyclopedia. Santa Barbara: ABC-CLIO, 2007, 226 Mũzkraa lị̄āmt Nāmūzj Lĩ Māthạ Al-Hãđāraa Al-Māṣīaa. https://www.faroukmisr.net/report141.htm, accessed in : May 2019

New York Times, February 10, 1949
O,Kane, Bernard. The Illustrated Guide to the Museum of Islamic Art in Cairo. Cairo: the American University in Cairo Press, 2012.

O'Neill, John P. The Vatican Collections: The Papacy and Art. New York: Metropolitan Museum of Art, 1982.

Obenga, Théophile and Amon Saba Saakana. Ancient Egypt and Black Africa. A Students Handbook for the Study of Ancient Egypt in Philosophy, Linguistics, and Gender Relations. London; Karnak House, 1992

Orsenigo, Christian. "Turning Points in Egyptian Archeology 1850-1950." In Egypt and the Pharaohs from the Sand to the libry. Phare Pine

avenir agricole et financier. Notes et documents sur la richesse et la fécondité du sol, suivis d’une nouvelle étude sur les irrigations. Paris: Librairie Poly Technique Baudry ET Cie, Editeure, 1884.

Plutarch, Moralia. De Exilio, Book VII.

Polybius, The Histories, Book VIII.

Prince Youssef Kamal: The Art Lover, Egyptian Chronicles, https://egyptchronicles.blogspot.com, accessed in: 25 ${ }^{\text {th June }}$ 2019.

Prophyry. Vita Pythagorac.

Cundon: British Museum, 2018, https://www britishmuseum. org/pdf/Asyut\%20Guardian\%20City.pdf.

- Reid, Donald Malcolm. "Cultural Imperialism and Nationalism: The Struggle to Define and Control the Heritage of Arab Art in Egypt." International Journal of Middle East Studies 24, no. 1, (1992): 57-76.

Reid, Donald Malcolm. “Indigenous Egyptology: The Decolonization of a Profession?" Journal of the American Oriental Society 105, no. 2 (April- June 1985): 233-246.

Reid, Donald Malcolm. "Nationalizing the Pharaonic Past: Egyptology, Imperialism, and the Eoyptian Nationalism, 1922 1952" "i Rethinking "Nationlism in the Arab Middle Fast, edited by Israel Cershoni and James P. Jankowski, 127-49. New York: Columbia University Press, 1997.

Reid, Donald Malcolm. "The Egyptian Geographical Society: From Foreign Layman’s Society to Indigenous Professional Association." Poetics Today 14, no. 3, Cultural Process in Musim and Arab Societies: Modern Period I (Autumn, 1993): 539-72.

Reid, Donald Malcolm. Contesting Antiquity in Egypt: Archaeologies, Museums and the Struggle for Identities from World War I to Nasser. Cairo: the American University in Cairo Press, 2012.

Reid, Donald Malcolm. Whose Pharaohs? Archeology, Museums, and Eoyptian National Identity from Napoleon to World War I. Berkeley, Los Angeles, London: University of California Press, 2002.

Rhone, Arthur. Coup doeeil sur létat présent du Caire ancient et modern. Paris: A. Quantin, 1882

Richter, Daniel S. Cosmopolis. Imagining Community in Late Classical Athens and the Early Roman Empire. New York: Oxford University Press, 2011

Rowll, Henry T. «A Home for the Muses.» Archaeology 19, no. 2, (April 1966): 76-83.

Savvopoulos, Kyriakos and Robert Steven Bianchi. Alexandrian Sculpture in the Graeco-Roman Museum. Bibliotheca Alexandrina, Graeco-Roman Museum, Series 1, The Alexandria and Mediterranean Research Center. Alexandria Bibliotheca Alexandrina, 2012.

Sayce, Archibald Henry. Reminiscenes. London: Macmillan,1923.

Schure, Edouard. Pythagoras and the Delphic Mysteries. London: William Ride \& Son, 1906.

Seif El-Din, Mervat. "The Greco-Roman Museum of Alexandria. Past, Present, and Future," Bibliotheca Alexandrina. Alex Med Newsletter 20 (August-October 2010): 7-9.

Shah, Ikbal Ali. Fouad, King of Egypt. London: H. Jenkins, 1936

Sheehan, Peter. Babylon of Egypt. The Archaeology of Old Cairo and the Origins of the City. Cairo: The American University in Cairo Press, 2010.

Simaika, Marcus. Dālīi Al- Mãthạaf Al-Qebti we Aham Al-Kana’es we Al-Adyerah Al-Atarareyah I. Cairo: El-Matba‘a Elamiriah, 1930.

Simmons, John E. Museums: A History. New York: Rowman \& Littlefield, 2016.

Simpson, Thomas. "The Museum as Grove of the Muses.” Journal of Museum Education 25, no. 1/2 (Spring- Summer 2000): $28-31$.

Strabo, Geography, Book XIII, XVII.

"The Egyptian Geological Museum.", State Information Service (SIS): http://www.sis.gov.eg/Story/1256/TheEgyptian-Geological-Museum?lang=en-us. Accessed in May 2019.

Tristant, Yann Marcel Charles. “Jean Clédat et le site de Béda: données nouvelles sur une découverte protodynastique dan 
le Sinaï septentrional.” BIFAO 104, (2004): 457-475.

- Volait, Mercedes. "Amateurs français et dynamique patrimoniale: aux origines du Comité de conservation des monuments de l'art arabe." In La France et l'Egypte à l'époque des vice-rois (1805-1882), edited by André Raymond \& Daniel Panzac, 311-25, Cairo: IFAO, 2002.

- Wainwright, G. A. "Seshat and the Pharaoh.” Journal of Egyptian Archaeology 26, (1941): 33-40.

- Warner, Nicholas. Guide to the Gayer-Anderson Museum Cairo. Cairo: Ministry of Culture, Supreme Council of Antiquities, 2003.

- Wien, Peter. Arab Nationalism, The Politics of History and Culture in the Modern Middle East. London and New York: Routledge Taylor \& Francis Group, 2017.

- Wilkinson, John Gardner. Modern Egypt and Thebes: Being a Description of Egypt; Including the Information Required for Travelers in the Country. Vol. I, London: John Murray, 1843.

- Wittlin, Alma Stephanie. The Museum. Its History and its Tasks in Education. London: Routledge \& K. Paul, 1949.

- Yasser, Ahmed. "Geological Museum. Scientific Iconic Mark in Cairo." Sada El-Balad English (August 22, 2019), https:// see.news/geological-museum-scientific-iconic-in-cairo/, accessed in: May 2019.

- Young Lee, Paula. "The Musaeum of Alexandria and the Formation of the Muséum in Eighteenth-Century France." The Art Bulletin 79, no. 3, (Sep., 1997): 385-412.

- Zākī, Abd Al-Raḥmān. Dor Al-Toḥaf fi Misr we Al-Gam 'yat Al 'almeya. Cairo: Dar Al-Nil lil Tba áh, 1949.

- Zākī, ’Abd Al-Raḥmān. Mawso ‘ at Madinat Al-Qahīra fi Alf ‘am, Al-Qahīra. Maktabt Al-Anglo Al-Masriah, 1969.

- Zākī, Abd Al-Raḥmān. Dālīl Mãtḥaf Al-Hīāaa Al-Qūmīaa līskk Hdīid Māṣr, Cairo: Matab` Al-Sikka Al-Hdīî,1991. 